\title{
Wykorzystanie Google Scholar do identyfikowania najczęściej cytowanych badaczy i ich prac naukowych. Przypadek publikacji z zakresu nauki o informacji w języku polskim
}

\author{
Zbigniew Osiński \\ ORCID: 0000-0003-4484-7265 \\ Instytut Nauk o Kulturze, Wydziat Humanistyczny \\ Uniwersytet Marii Curie-Skłodowskiej w Lublinie
}

\begin{abstract}
Abstrakt
Cel/Teza: Ustalenie, czy Google Scholar (GS) umożliwia wiarygodną identyfikację najczęściej cytowanych badaczy i ich prac naukowych opublikowanych w języku polskim. Określenie, czy liczba cytowań i stosowanie słów kluczowych są istotnymi kryteriami hierarchizacji wyników wyszukiwania w GS. Stworzenie rankingu najczęściej cytowanych polskich badaczy i prac z zakresu nauki o informacji w okresie 2010-2019. Weryfikacja hipotezy, sugerującej, że zarówno obecność danej pracy w wynikach wyszukiwania, jak i pozycję na liście tych wyników, zaburza problem słów kluczowych tej publikacji, np. ich brak.

Koncepcja/Metody badań: Weryfikacja i analiza ilościowa danych pobranych z Google Scholar. Próbę badawczą wyodrębniono za pomocą czterdziestu pytań wyszukiwawczych, którymi były wyrażenia kluczowe dla nauki o informacji oraz dodatkowo imiona i nazwiska badaczy z tej dyscypliny. Wyniki i wnioski: W przypadku haseł wyszukiwawczych w języku polskim nie znajduje potwierdzenia teza mówiąca, iż wyszukiwarka Google Scholar nadaje się do niezawodnej identyfikacji najczęściej cytowanych prac i badaczy. Znacząca statystycznie część prac indeksowanych w GS nie pojawia się w wynikach wyszukiwania przy zastosowaniu wyrażeń związanych z nauką o informacji. Duża grupa często cytowanych tekstów umieszczona jest na bardzo dalekich miejscach w wynikach wyszukiwania. Nie znajduje także potwierdzenia teza mówiąca, że głównym kryterium szeregowania prac naukowych w wynikach wyszukiwania jest liczba cytowań. Zdecydowana większość pozycji bibliograficznych w wynikach wyszukiwania GS nie jest adekwatna do intencji wyszukującego. Właściwe zastosowanie słów kluczowych w metadanych publikacji nie zwiększa jej szansy na wyszukanie w Google Scholar za pomocą polskich terminów wyszukiwawczych.

Oryginalność/Wartość poznawcza: Praca obala coraz bardziej popularne przekonanie o tym, że Google Scholar można profesjonalnie wykorzystywać do wyszukiwania najbardziej wartościowych (a raczej stosunkowo często cytowanych) prac naukowych oraz do formułowania ocen (bazujących na cytowaniach) tychże opublikowanych w języku polskim i badaczy publikujących głównie w tym języku.
\end{abstract}

\section{Słowa kluczowe}

Cytowania pracy naukowej. Google Scholar. Nauka o informacji. Ranking wyników wyszukiwania.

Otrzymany: 28 stycznia 2021. Zrecenzowany: 18 kwietnia 2021. Poprawiony: 28 kwietnia 2021.

Zaakceptowany: 13 maja 2021. 


\section{Wprowadzenie}

Od ponad dekady w polskiej humanistyce i naukach społecznych coraz większy wpływ zdobywa pogląd mówiący, że liczba cytowań uzyskanych przez badacza lub pracę naukową świadczy o sile wpływu na rozwój nauki, a pośrednio także o naukowej jakości tegoż badacza lub pracy. Pogląd ten początkowo, w drugiej połowie XX w., rozpowszechnił się w naukach ścisłych, przyrodniczych, o zdrowiu i inżynieryjno-technicznych. We wspomnianych dziedzinach przyjęło się przekonanie, że dla wyrobienia sobie opinii o badaczu i jego pracach istotne jest zliczanie cytowań w publikacjach zarejestrowanych w bibliograficznej bazie danych Web of Science (a ostatnio także Scopus). Obecność w tej (tych) bazie (bazach) uznawana jest bowiem za gwarancję wysokiej jakości naukowej czasopisma, a pośrednio także pracy w nim opublikowanej. Jednakże ten system nie sprawdza się w przypadku większości dyscyplin z nauk humanistycznych i społecznych uprawianych w Polsce. Powodem są zarówno różnice $\mathrm{w}$ zwyczajach publikacyjnych pomiędzy badaczami z poszczególnych dyscyplin naukowych, jak i fakt, że czasopisma z nauk humanistycznych i społecznych, które wydawane są w innych językach niż angielski, przez wydawców innych niż międzynarodowe koncerny wydawnicze, nie posiadają odpowiednio licznej reprezentacji w obu bazach, pozwalającej na racjonalne i obiektywne wyliczenia oraz analizy (Osiński, 2019).

Nie stworzono jeszcze odpowiednio zasobnych baz cytowań bibliograficznych, które zapewniłyby wiarygodne wyniki automatycznego zliczania cytowań prac polskich badaczy z nauk humanistycznych i społecznych, toteż pojawia się istotny problem: w jaki sposób pozyskać dane pozwalające w miarę precyzyjnie określić, jak dużo cytowań zdobyły prace poszczególnych polskich badaczy? Rozwiązanie tego problemu jest ważne dla wszystkich prowadzących badania naukometryczne i bibliometryczne oraz dla tych, którzy, przygotowując projekt badawczy, poszukują najważniejszych (a więc najbardziej wpływowych, czyli najczęściej cytowanych) prac na dany temat. Do tego należy uwzględnić fakt, że od ponad dekady upowszechniają się poglądy, których autorzy oceniają pozycję polskiej nauki, uczelni, instytutów i badaczy na podstawie danych dotyczących cytowań (np. Siłka et al., 2016; Śleszyński, 2013; Wróblewski, 2013). Ponadto aktualny system oceny parametrycznej dyscyplin naukowych w kryterium pierwszym opiera się na rankingu czasopism, który w dużym stopniu uwzględnia cytowania zdobywane przez artykuły opublikowane w danym periodyku. Tak więc liczba cytowań staje się informacją kluczową dla naukowych badań i karier. Czy receptą na braki w zakresie informacji o cytowaniach może być wykorzystanie Google Scholar (GS), wyszukiwarki prac naukowych uznanej kilka lat temu za „najbardziej reprezentatywną aproksymację danych o cytowalności z obszaru nauk społeczno-humanistycznych" (Racki \& Drabek, 2013)?

\section{Stan badań}

W literaturze naukowej z ostatnich lat pojawił się pogląd sugerujący, że do niezawodnej identyfikacji najczęściej cytowanych badaczy i ich prac wystarczająco dobrze nadaje się wyszukiwarka Google Scholar, która indeksuje literaturę naukową w szerokim zakresie dyscyplin, typów dokumentów i języków (m.in. Beel et al., 2010; Delgado López-Cózar et al., 2019; Martin-Martin et al., 2017; Stribu et al., 2015). GS specjalizuje się w wyszukiwaniu 
i identyfikacji pełnych tekstów prac naukowych, danych bibliograficznych o charakterze naukowym, a także świadczy szereg usług, takich jak np. zliczanie cytatów otrzymanych przez każdy dokument. Stwierdzono, że wyniki wyszukiwania w GS w dużym stopniu pokrywają się z wynikami kwerend w komercyjnych bazach danych bibliograficznych. Ponadto GS zapewnia liczne informacje o pracach naukowych, które nie są zarejestrowane w Web of Science i Scopus, co może być przydatne dla badaczy w uzyskaniu pełniejszego obrazu konkretnej problematyki badawczej. Wyszukiwarka ta została określona mianem lidera pod względem liczby wyników bez względu na zastosowane terminy wyszukiwawcze (Stribu et al., 2015).

Ustalono, że co prawda funkcjonowanie algorytmów, za pomocą których odsiewane są treści naukowe od nienaukowych oraz tworzona jest posortowana lista wyników, stanowi tajemnicę handlową firmy Google, to jednak możliwe jest opracowanie zasad optymalizacji pod kątem uzyskania przez daną pracę miejsca na pierwszych stronach wyników. Na miejsce w wynikach wyszukiwania wpływa bowiem częstotliwość występowania w tekście wyrażenia, które zostało użyte jako wyrażenie wyszukiwawcze oraz liczba cytowań tego tekstu. Istotne są także szczegóły techniczne pliku PDF takie, jak: wpisanie właściwych metadanych do metryczki pliku, zamieszczenie na początku tekstu danych autorów, tytułu pracy i abstraktu, stosowanie stylów akapitowych dla śródtytułów, stosowanie szczegółowych słów kluczowych (raczej terminów wielowyrazowych niż pojedynczych wyrazów) i częste ich używanie (a także ich synonimów) we właściwych miejscach nie tylko w samym tekście: w: metadanych, tytule, śródtytułach, nazwach tabel i grafik oraz zachowanie schematu tekstu właściwego dla pracy naukowej - wstęp, stan badań, wyniki, wnioski, bibliografia (Beel et al., 2010).

Za istotną zaletę tej wyszukiwarki uznano uwzględnianie takich źródeł artykułów, które nie występują w Web of Science i Scopus, co pozwala uzyskać szersze spojrzenie na dorobek naukowy wielu badaczy, zwłaszcza w naukach humanistycznych i społecznych (Delgado López-Cózar et al., 2019). Inne badania sugerują, że co prawda GS systematycznie rozszerza zakres indeksowanych dokumentów naukowych, to jednak korzystanie z wyników wyszukiwania powinna cechować duża ostrożność. Mechanizmy tej wyszukiwarki nie odróżniają bowiem prac recenzowanych od nierecenzowanych i są podatne na manipulowanie cytowaniami (Halevi et al., 2017). Ustalono też, że liczba cytowań jest kluczowym czynnikiem w rankingu wyników: istnieje silny związek pomiędzy cytowaniami dokumentu a jego pozycją w wynikach wyszukiwania, a zatem GS jest w stanie skutecznie identyfikować wysoko cytowane prace (Martin-Martin et al., 2017). Wyrażono przy tym przypuszczenie, że czynnikiem zaburzającym związek pomiędzy liczbą cytowań danej pracy, a miejscem tej pracy w wynikach wyszukiwania jest język publikacji. Okazało się bowiem, że w przypadku gdy wysyła się tzw. zerowe zapytanie (w wyszukiwaniu zaawansowanym określa się jedynie rok wydania poszukiwanych publikacji, zaś pole do wpisywania wyrażeń wyszukiwawczych pozostaje puste), to publikacje w językach innych niż angielski GS umieszcza na odległych pozycjach, nawet jeżeli są stosunkowo często cytowane. Problem ten może istotnie zaburzać wyniki wyszukiwania w stosunku do prac nieanglojęzycznych, bowiem GS udostępnia jedynie pierwszy tysiąc rekordów na każde zapytanie (Martin-Martin et al., 2017). Stąd też, chcąc odpowiedzieć na pytanie, czy GS nadaje się do identyfikowania najczęściej cytowanych prac naukowych i badaczy także w języku polskim, należy przeprowadzić odpowiednie badania, ale z ograniczeniem do stawiania pytań wyszukiwawczych jedynie w języku polskim. 
W przypadku wykorzystywania GS do badania dorobku badaczy z zakresu nauki o informacji (ang. information science) dotychczas ustalono, że możliwe jest stosowanie informacji zawartych w profilach badaczy z tej dyscypliny w Google Scholar Citations do wieloaspektowej analizy tej dyscypliny i do dokładnego zobrazowania społeczności naukowców. Jednakże konieczne jest ręczne przetworzenie pobranych informacji - uzupełnienie brakujących danych i usunięcie duplikatów (Martin-Martin et al., 2018).

\section{Cele i metodologia badań}

W związku z powyższym autor przeprowadził badania, które miały na celu ustalenie, czy Google Scholar umożliwia na tyle wiarygodną i kompletną identyfikację najczęściej cytowanych badaczy i prac naukowych opublikowanych w języku polskim, by jakość uzyskanych danych pozwalała na ich naukowe zastosowanie. Istotne było też ustalenie, czy liczba cytowań i stosowanie określonych słów kluczowych w języku polskim, przez autorów i wydawców, wpływa na sortowanie wyników wyszukiwania w GS (co sugerują badania opisane powyżej). Ponadto, poddano weryfikacji hipotezę sugerującą, że zarówno obecność danej pracy w wynikach wyszukiwania, jak i pozycję na liście tych wyników, zaburza problem słów kluczowych publikacji, np. ich brak.

Badania ograniczono do prac i autorów związanych z nauką o informacji (informatologią), która to dyscyplina według formalnego podziału nauk i dyscyplin naukowych w Polsce od 2019 r. należy do zakresu nauk o komunikacji społecznej i mediach. Przyjęte ograniczenie wiąże się z drugim celem badań, którym był zamiar stworzenia rankingu polskich badaczy i prac z tej dyscypliny (tym razem bez ograniczenia do języka polskiego), którego jedynym kryterium byłaby cytowalność. Zakres czasowy pobieranych danych ograniczono więc do okresu 2010-2019. Badanie zrealizowano w trzech etapach opisanych poniżej.

\subsection{Etap 1. Gromadzenie materiału badawczego}

W pole wyszukiwawcze wpisano czterdzieści wyrażeń, którymi były terminy uznane za kluczowe dla nauki o informacji (wzięte w cudzysłów). Autor zastosował następujące kryteria wyboru tych terminów: dwie wersje nazwy dyscypliny: nauka o informacji, informatologia; dziesięć terminów najczęściej występujących jako słowa kluczowe w artykułach opublikowanych w latach 2010-2018 w czasopismach związanych z badaną dyscypliną, obecnych na dawnej (istniejącej do 2018 r.) ministerialnej liście B (Osiński, 2019): zarządzanie informacją, biblioteki akademickie, kompetencje informacyjne, komunikacja naukowa, język haseł przedmiotowych, rozwój dyscyplin naukowych, wyszukiwanie informacji, języki informacyjno-wyszukiwawcze, metody ilościowe w informatologii, czasopisma naukowe. Kolejne dwadzieścia osiem terminów autor wybrał na podstawie analizy artykułu Barbary Sosińskiej-Kalaty Obszary badań wspótczesnej informatologii (nauki o informacji) (2013) oraz książki Nauka o informacji, wydanej pod redakcją Wiesława Babika (2016) jako nazwy podstawowych obszarów badań nauki o informacji: teoria informacji, architektura informacji, procesy informacyjne, systemy informacyjne, zasoby informacyjne, ekologia informacji, bibliometria, bariery informacyjne, użytkownicy informacji, etyka informacyjna, źródła informacji naukowej, środowisko informacyjne, organizacja informacji, zachowania 
informacyjne, kultura informacyjna, bibliografia załącznikowa, wizualizacja informacji, bibliograficzna baza danych, działalność informacyjna, naukometria, infobrokerstwo, czasopisma open access, biblioteki cyfrowe, bezpieczeństwo informacyjne, reprezentacja informacji, potrzeby informacyjne, obiekty informacyjne, przestrzeń informacyjna.

Z uzyskanych rezultatów wykluczono patenty oraz prace, które, ze względu na tematykę oraz miejsce publikacji (czasopismo/wydawnictwo) lub autora, związane były z takimi dyscyplinami jak: informatyka, nauki o zarządzaniu, ekonomia, medioznawstwo, pedagogika, nauki o administracji. Przyjęto założenie, że w przypadku niemożności w miarę jednoznacznego skojarzenia tematyki pracy z nauką o informacji, o zakwalifikowaniu do badań zadecyduje współwystępowanie autora lub czasopisma/wydawnictwa jednoznacznie związanego, według informacji dostępnych na stronach WWW poszczególnych uczelni oraz wiedzy autora niniejszego artykułu, z tą dyscypliną naukową. Do dalszych analiz nie zakwalifikowano też materiałów, które nie miały charakteru publikacji naukowej (brak elementów typowych dla takiej publikacji, np. bibliografii lub właściwej struktury). Ostatecznie materiał badawczy stanowiło 259 prac spełniających opisane powyżej kryteria (plik $\mathrm{z}$ danymi i rankingiem cytowań tych prac dostępny w RepOD - https://repod.icm.edu.pl).

Konieczna okazała się weryfikacja cytowań, albowiem GS do cytowań danej pracy naukowej zalicza także: cytowania pochodzące z dostępnych w Internecie prezentacji, prospektów reklamowych, nieopublikowanych wystąpień konferencyjnych, programów kształcenia oraz sylabusów przedmiotów, duplikaty cytowań, a także autocytowania. Wśród cytowań trafiają się również takie, które nie prowadzą do jakiejkolwiek pracy cytującej. Liczba cytowań zaburzających obiektywny obraz cytowalności prac związanych z danym wyrażeniem wyszukiwawczym przekracza w niektórych przypadkach nawet $30 \%$ wszystkich cytowań wykazanych przez GS (dla wyrażeń wyszukiwawczych: bibliometria, użytkownicy informacji, bibliografia załącznikowa, naukometria, obiekty informacyjne). W przypadku połowy wyrażeń odsetek takich cytowań przekracza $20 \%$.

Tak więc liczbę cytowań podawaną przez GS zweryfikowano poprzez analizę każdego rekordu. Pomniejszono ją o autocytowania, powtórzenia cytowań tej samej pracy, cytowania pochodzące z prezentacji, z programów kształcenia i sylabusów, z wystąpień konferencyjnych, które nie zostały opublikowane oraz takie cytowania, których źródła GS nie podaje w sposób niebudzący wątpliwości skąd pochodzą. W celu ograniczenia ilości informacji do zakresu niezbędnego z punktu widzenia realizacji celów badań, analizy przeprowadzono z uwzględnieniem tekstów, które uzyskały przynajmniej trzy zweryfikowane cytowania.

\subsection{Etap 2. Weryfikacja kompletności materiału badawczego}

Kompletność danych, w sensie uwzględnienia w zestawie wyników wyszukiwania możliwie wszystkich publikacji spełniających opisane powyżej kryteria i indeksowanych przez Google Scholar, sprawdzono w drugim etapie badania. Polegał on na przeprowadzeniu wyszukiwania za pomocą nazwisk i imion (wziętych w cudzysłów) 41 badaczy, których nazwiska pojawiły się w wynikach wyszukiwania w pierwszym etapie badań i którzy w okresie 2010-2019 zaliczani byli do reprezentantów nauki o informacji (według informacji dostępnych na stronach WWW poszczególnych uczelni oraz wiedzy autora). Początkowo wyniki ograniczono do języka polskiego. Szukano w nich prac, które nie pojawiły się na poprzednich czterdziestu listach z wynikami wyszukiwania, a które uzyskały przynajmniej trzy zweryfikowane 
cytowania. Chcąc stworzyć pełny ranking prac stosunkowo często cytowanych, powtórzono wyszukiwanie według autorów, ale z uwzględnieniem wszystkich języków.

\subsection{Etap 3. Weryfikacja hipotezy o zwiazku miejsca publikacji na liście wyników $z$ wystęowaniem wyrażeń wyszukiwawczych wśród metadanych tej publikacji}

Trzeci etap badań zrealizowano w związku z tym, że w poprzednich etapach okazało się, iż porządek pozycji bibliograficznych w wynikach wyszukiwania w GS w dużej części przypadków nie był oparty na liczbie cytowań poszczególnych publikacji (wbrew sugestiom innych badań, omówionych w przeglądzie piśmiennictwa). Nie stwierdzono też istotnego związku pomiędzy tym, w ilu wynikach wyszukiwania pojawiała się dana praca, a tym, ile uzyskała cytowań. Fakt ten sprzeczny jest z racjonalnym przekonaniem sugerującym, że im częściej (w odpowiedzi na więcej wyrażeń wyszukiwawczych) dana praca pojawia się w wynikach Google Scholar (wyszukiwarki powszechnie stosowanej przez środowisko naukowe), tym więcej ma szans na cytowanie.

W związku z tym postanowiono poddać weryfikacji wstępną hipotezę, sugerującą, że zarówno obecność danej pracy w wynikach wyszukiwania, jak i jej pozycję na liście tych wyników, zaburza problem słów kluczowych. Szukano więc słów kluczowych w tytule, tekście (w pozycji „słowa kluczowe”), metryce pliku, na stronie WWW wydawcy/czasopisma lub w bibliotece cyfrowej/repozytorium, gdzie plik z tekstem został udostępniony. Ponadto przyjrzano się drugiemu z czynników mogących wpływać na sortowanie wyników wyszukiwania w GS - zgodności użytych w pracy (w miejscach wymienionych powyżej) słów kluczowych z wyrażeniami wyszukiwawczymi, dzięki którym dana praca została wyszukana. Jak można wstępnie domniemywać, skoro dana praca została wyszukana przy użyciu np. terminu „biblioteka cyfrowa”, znaczy, że tekst lub jego opis na stronie WWW powinien zawierać ten termin przynajmniej kilkukrotnie. Na tym etapie, ze względu na konieczność minimalizowania ilości danych, które pomieściłyby się w ramach jednego artykułu, badanie ograniczono do prac najczęściej cytowanych, co najmniej dwadzieścia razy, lub wyszukanych za pomocą co najmniej siedmiu wyrażeń wyszukiwawczych (bez nazwisk i imion autorów). Uwzględniono dwadzieścia prac, których pełne teksty w formacie PDF lub HTML dostępne były w Internecie bez opłat i konieczności logowania się.

Dane zbierano w okresie od maja do października 2020 r., a więc wyniki badań nie uwzględniają późniejszych zmian w zasobach Google Scholar.

\section{Wyniki badań}

\subsection{Identyfikacja stosunkowo często cytowanych badaczy i ich publikacji}

Wyszukiwanie przeprowadzone w zasobie danych Google Scholar wykazało obecność 259 prac spełniających opisane powyżej kryteria (plik z danymi i rankingiem cytowań tych prac dostępny w RepOD - https://repod.icm.edu.pl). W tym zestawie znalazło się 59 publikacji, które w realiach polskiej nauki o informacji można uznać za stosunkowo często cytowane: każda z nich otrzymała co najmniej 10 cytowań (Zał. 1). 
Autorami lub współautorami prac wyszukanych w GS jest 157 osób w tym: Marzena Świgoń - 17 prac, Wiesław Babik - 10, Aneta Drabek - 10, Ewa Głowacka - 8, Emanuel Kulczycki - 8, Ewa A. Rozkosz - 8, Sabina Cisek - 7, Władysław M. Kolasa - 7, Jacek Wojciechowski - 7, Lidia Derfert-Wolf - 6, Małgorzata Kisilowska - 6, Veslava Osińska 6, Hanna Batorowska - 5, Justyna Jasiewicz - 5, Małgorzata Kowalska - 5, Małgorzata Fedorowicz-Kruszewska - 4, Grzegorz Gmiterek - 4, Mirosław Górny - 4, Marek Nahotko 4, Stanisław Skórka - 4, Marcin Werla - 4, Jadwiga Woźniak-Kasperek - 4, Małgorzata Janiak - 3, Barbara Kamińska-Czubała - 3, Katarzyna Materska - 3, Marcin Roszkowski - 3, Barbara Sosińska-Kalata - 3, Piotr Tafiłowski - 3, Magdalena Wójcik - 3.

Dominują artykuły w czasopismach - 158 (61\%), z czego 29 opublikowano w periodykach zagranicznych. Wyszukano też 66 artykułów w pracach zbiorowych (25,5\%) oraz 35 monografii (13,5\%). W przypadku artykułów w czasopismach polskich dominują opublikowane w: Biuletynie EBIB - 22, Przegladzie Bibliotecznym - 20 oraz w Zagadnieniach Informacji Naukowej- 18.

Spośród 259 prac, 203 wyszukano przy użyciu jednego z czterdziestu wyrażeń wyszukiwawczych. Kolejne 31 wyszukano stosując imię i nazwisko badacza z ograniczeniem do języka polskiego, a następne 25 - likwidując to ograniczenie. Tak więc prawie $22 \%$ prac, spośród cytowanych co najmniej trzy razy, nie pojawiło się w wynikach wyszukiwania GS, jeżeli zastosowano związane z nauką o informacji wyrażenia wyszukiwawcze w języku polskim.

Autorami lub współautorami 59 prac cytowanych co najmniej dziesięć razy (Zał. 1) jest 40 autorów, wśród których zdecydowanie dominuje M. Świgoń - autorka lub współautorka 13 publikacji zaindeksowanych przez GS. Liczebnością prac w tym zestawieniu wyróżnił się także W.M. Kolasa - 5 publikacji oraz E. Kulczycki - 4 publikacje.

Do najczęściej cytowanych prac należą monografie - 21 spośród 35 wyszukanych oraz artykuły w czasopismach zagranicznych - 16 spośród 29 wyszukanych.

W zestawie prac cytowanych co najmniej dziesięć razy, 38 wyszukano stosując słowa kluczowe, 8 stosując imię i nazwisko badacza z ograniczeniem do języka polskiego, a następne 13 - likwidując to ograniczenie. Tak więc, jeżeli zastosowano polskie terminy wyszukiwawcze związane z nauką o informacji, spośród prac cytowanych stosunkowo najczęściej, prawie $36 \%$ nie pojawiło się w wynikach wyszukiwania w GS.

\subsection{Liczba wyrażeń wyszukiwawczych związanych z publikacją i jej miejsce na liście wyników a liczba zdobytych cytowań}

Okazało się, że poszczególne prace pojawiały się na listach wyników przy bardzo zróżnicowanej liczbie zapytań wyszukiwawczych. W skrajnych przypadkach zidentyfikowano publikacje, które na listach wyników pojawiły się w odpowiedzi na zastosowanie od jedenastu do jednego wyrażenia wyszukiwawczego. Stwierdzono, że skojarzenie konkretnego tekstu ze stosunkowo dużą liczbą wyrażeń wyszukiwawczych, co teoretycznie powinno dawać większą szansę na znalezienie tej publikacji w zasobach Internetu, nie koresponduje w sposób wyraźny z większą liczbą cytowań (Tab. 1). Wśród 24 prac występujących przynajmniej w pięciu wynikach wyszukiwania znajdujemy 6 publikacji spośród 38 cytowanych co najmniej dziesięć razy (16\%). Na pozostałe 165 prac, cytowanych mniej niż dziesięć razy, przypada 18 publikacji występujących przynajmniej w pięciu wynikach wyszukiwania (11\%). W prawie połowie przypadków wykazana przez GS praca pojawiła się jedynie 
w jednym wyniku wyszukiwania - 99 na 203 (49\%). Taka sytuacja dotyczyła 21 spośród 38 prac cytowanych dziesięć i więcej razy (55\%), co potwierdza brak wyraźnego związku pomiędzy potencjalną szansą na znalezienie tekstu pracy w GS (liczba skojarzonych z nią wyrażeń wyszukiwawczych), a jej cytowalnością, w sytuacji, gdy stosujemy wyrażenia wyszukiwawcze w języku polskim.

Jednego z wyjaśnień takiego stanu rzeczy dostarcza analiza pozycji danej pracy w wynikach wyszukiwania. Okazuje się, że najczęściej jest to odległa pozycja, poza kilkoma pierwszymi stronami wyników, które zdecydowana większość użytkowników Internetu sprawdza. Na 24 prace z grupy wyszukanych za pomocą pięciu i więcej terminów przypada w sumie 158 rekordów. Z tego jedynie 27 rekordów (17\%) pojawiło się na pierwszych trzech stronach wyników. Na trzeci i czwarty kwartyl listy wyników wyszukiwania, czyli tam, gdzie niewielu poszukujących dociera, przypada 56 (35.5\%) wyszukanych rekordów. Jeżeli podobnej analizie poddamy zbiór 38 prac cytowanych co najmniej dziesięć razy, a wyszukanych z zastosowaniem wyrażeń wyszukiwawczych (Zał. 1), to okazuje się, że uzyskanych rekordów było 91 . Z tego 25 (27.5\%) znalazło się na pierwszych trzech stronach wyników. Zaś w trzecim i czwartym kwartylu listy wyników wyszukiwania było ich 44 (48\%). Tak więc sugestia Beel et al. (2010), iż jednym z czynników wpływających na pozycję pracy w wynikach wyszukiwania GS jest liczba cytowań, w przypadku stosowania haseł wyszukiwawczych w języku polskim nie znajduje potwierdzenia. W zależności od zastosowanego wyrażenia wyszukiwawczego, prawie połowa prac stosunkowo często cytowanych pojawia się dopiero w trzecim i czwartym kwartylu listy wyników.

Tabela 1. Prace wyszukane za pomocą pięciu i więcej wyrażeń wyszukiwawczych

\begin{tabular}{|c|c|c|c|c|}
\hline L.p. & Autor & Tytuł & $\begin{array}{c}\text { Liczba } \\
\text { zweryfi- } \\
\text { kowanych } \\
\text { cytowań }\end{array}$ & $\begin{array}{l}\text { Wyrażenia i strona w wynikach / } \\
\text { liczba stron wyników }\end{array}$ \\
\hline 1 & 2 & 3 & 4 & 5 \\
\hline 1 & Babik W. & $\begin{array}{l}\text { Ekologia informacji } \\
\text { katalizatorem } \\
\text { równoważenia } \\
\text { rozwoju } \\
\text { społeczeństwa } \\
\text { informacji i wiedzy }\end{array}$ & 9 & $\begin{array}{l}\text { 1. Zarządzanie informacją } 50 / 100 \\
\text { 2. Kompetencje informacyjne } \\
28 / 57 \\
\text { 3. Wyszukiwanie informacji } \\
16 / 100 \\
\text { 4. Procesy informacyjne } 28 / 53 \\
\text { 5. Ekologia informacji } 1 / 21 \\
\text { 6. Bariery informacyjne } 6 / 29 \\
\text { 7. Użytkownicy informacji } 1 / 25 \\
\text { 8. Srodowisko informacyjne } 9 / 21 \\
\text { 9. Zachowania informacyjne } 15 / 29 \\
\text { 10. Przestrzeń informacyjna } 16 / 44 \\
\text { 11. Potrzeby informacyjne } 44 / 100\end{array}$ \\
\hline
\end{tabular}




\begin{tabular}{|c|c|c|c|c|}
\hline 1 & 2 & 3 & 4 & 5 \\
\hline 2 & $\begin{array}{l}\text { Sosińska- } \\
\text { Kalata B. }\end{array}$ & $\begin{array}{l}\text { Obszary badań } \\
\text { współczesnej } \\
\text { informatologii } \\
\text { (nauki o informacji) }\end{array}$ & 25 & $\begin{array}{l}\text { 1. Nauka o informacji } 1 / 51 \\
\text { 2. Informatologia } 19 / 34 \\
\text { 3. Kompetencje informacyjne } \\
33 / 57 \\
\text { 4. Komunikacja naukowa } 16 / 40 \\
\text { 5. Wyszukiwanie informacji } 3 / 100 \\
\text { 6. Procesy informacyjne } 37 / 53 \\
\text { 7. Bibliometria } 18 / 42 \\
\text { 8. Etyka informacyjna } 2 / 2 \\
\text { 9. Zachowania informacyjne } 15 / 29 \\
\text { 10. Działalność informacyjna } 12 / 82\end{array}$ \\
\hline 3 & $\begin{array}{l}\text { Batorowska H., } \\
\text { Klepka R., } \\
\text { Wasiuta O. }\end{array}$ & $\begin{array}{l}\text { Media jako } \\
\text { instrument wpływu } \\
\text { informacyjnego } \\
\text { i manipulacji } \\
\text { społeczeństwem }\end{array}$ & 7 & $\begin{array}{l}\text { 1. Nauka o informacji } 20 / 51 \\
\text { 2. Kompetencje informacyjne } \\
19 / 57 \\
\text { 3. Teoria informacji } 68 / 100 \\
\text { 4. Procesy informacyjne } 45 / 53 \\
\text { 5. Ekologia informacji } 21 / 21 \\
\text { 6. Wyszukiwanie informacji } \\
93 / 100 \\
\text { 7. Architektura informacji } 21 / 28 \\
\text { 8. Bariery informacyjne } 21 / 29 \\
\text { 9. Użytkownicy informacji } 23 / 25 \\
\text { 10. Bezpieczeństwo informacyjne } \\
\text { 50/56 }\end{array}$ \\
\hline 4 & Jasiewicz J. & $\begin{array}{l}\text { Obszary, problemy } \\
\text { i metody badawcze } \\
\text { library and informa- } \\
\text { tion science. Część I }\end{array}$ & 3 & $\begin{array}{l}\text { 1. Nauka o informacji } 7 / 51 \\
\text { 2. Informatologia } 3 / 34 \\
\text { 3. Biblioteki akademickie } 60 / 71 \\
\text { 4. Kompetencje informacyjne } 5 / 57 \\
\text { 5. Wyszukiwanie informacji } \\
17 / 100 \\
\text { 6. Teoria informacji } 44 / 100 \\
\text { 7. Systemy informacyjne } 8 / 100 \\
\text { 8. Bibliometria } 14 / 42 \\
\text { 9. Zachowania informacyjne } 10 / 29\end{array}$ \\
\hline 5 & Babik W. & $\begin{array}{l}\text { Biblioteka } \\
\text { akademicka } \\
\text { na rozdrożu: } \\
\text { o współczesnych } \\
\text { przemianach } \\
\text { w środowisku } \\
\text { informacyjnym } \\
\text { bibliotek }\end{array}$ & 6 & $\begin{array}{l}\text { 1. Biblioteki akademickie } 4 / 71 \\
\text { 2. Kompetencje informacyjne } \\
28 / 57 \\
\text { 3. Wyszukiwanie informacji } \\
44 / 100 \\
\text { 4. Teoria informacji } 58 / 100 \\
\text { 5. Systemy informacyjne } 8 / 100 \\
\text { 6. Srodowisko informacyjne } 4 / 21 \\
\text { 7. Kultura informacyjna } 15 / 39 \\
\text { 8. Przestrzeń informacyjna } 12 / 44 \\
\text { 9. Potrzeby informacyjne } 38 / 100\end{array}$ \\
\hline
\end{tabular}




\begin{tabular}{|c|c|c|c|c|}
\hline 1 & 2 & 3 & 4 & 5 \\
\hline 6 & $\begin{array}{l}\text { Woźniak- } \\
\text { Kasperek J. }\end{array}$ & $\begin{array}{l}\text { Języki } \\
\text { nformacyjne: } \\
\text { między tradycją } \\
\text { a nadzieją na cyfrową } \\
\text { przyszłość }\end{array}$ & 5 & $\begin{array}{l}\text { 1. Nauka o informacji } 22 / 51 \\
\text { 2. Biblioteki akademickie } 51 / 71 \\
\text { 3. Kompetencje informacyjne } 7 / 57 \\
\text { 4. Wyszukiwanie informacji } \\
68 / 100 \\
\text { 5. Architektura informacji } 18 / 28 \\
\text { 6. Użytkownicy informacji } 9 / 25 \\
\text { 7. Srodowisko informacyjne } 1 / 21 \\
\text { 8. Obiekty informacyjne } 1 / 5\end{array}$ \\
\hline 7 & Cisek S. & $\begin{array}{l}\text { Metoda analizy } \\
\text { i krytyki } \\
\text { piśmiennictwa } \\
\text { w nauce o informacji } \\
\text { i bibliotekoznawstwie } \\
\text { w XXI wieku }\end{array}$ & 20 & $\begin{array}{l}\text { 1. Nauka o informacji } 1 / 51 \\
\text { 2. Informatologia } 9 / 34 \\
\text { 3. Zarządzanie informacją } 93 / 100 \\
\text { 4. Biblioteki akademickie } 60 / 71 \\
\text { 5. Komunikacja naukowa } 23 / 40 \\
\text { 6. Bibliometria } 40 / 42 \\
\text { 7. Zachowania informacyjne } \\
19 / 29\end{array}$ \\
\hline 8 & Kisilowska M. & $\begin{array}{l}\text { Przestrzeń } \\
\text { informacyjna jako } \\
\text { termin } \\
\text { informatologiczny }\end{array}$ & 13 & $\begin{array}{l}\text { 1. Kompetencje informacyjne } 22 / 57 \\
\text { 2. Teoria informacji } 67 / 100 \\
\text { 3. Ekologia informacji } 13 / 21 \\
\text { 4. Środowisko informacyjne } 1 / 21 \\
\text { 5. Zachowania informacyjne } \\
19 / 29 \\
\text { 6. Działalność informacyjna } 7 / 82 \\
\text { 7. Przestrzeń informacyjna } 1 / 44\end{array}$ \\
\hline 9 & $\begin{array}{l}\text { Pamuła- } \\
\text { Cieślak N. }\end{array}$ & $\begin{array}{l}\text { Ukryty Internet jako } \\
\text { przedmiot edukacji } \\
\text { informacyjnej }\end{array}$ & 8 & $\begin{array}{l}\text { 1. Biblioteki akademickie } 46 / 71 \\
\text { 2. Komunikacja naukowa } 26 / 40 \\
\text { 3. Wyszukiwanie informacji } 9 / 100 \\
\text { 4. Teoria informacji } 53 / 100 \\
\text { 5. Bariery informacyjne } 16 / 29 \\
\text { 6. Kultura informacyjna } 18 / 39 \\
\text { 7. Przestrzeń informacyjna } 9 / 44\end{array}$ \\
\hline 10 & Babik W. & Słowa kluczowe & 35 & $\begin{array}{l}\text { 1. Język haseł przedmiotowych } \\
9 / 14 \\
\text { 2. Języki informacyjno-wyszuki- } \\
\text { wawcze } 9 / 12 \\
\text { 3. Teoria informacji } 60 / 100 \\
\text { 4. Organizacja informacji } 7 / 17 \\
\text { 5. Działalność informacyjna } 68 / 82 \\
\text { 6. Przestrzeń informacyjna } 38 / 44\end{array}$ \\
\hline 11 & Kotuła S.D. & $\begin{array}{l}\text { Komunikacja } \\
\text { bibliologiczna wobec } \\
\text { World Wide Web }\end{array}$ & 13 & $\begin{array}{l}\text { 1. Nauka o informacji } 29 / 51 \\
\text { 2. Informatologia } 29 / 34 \\
\text { 3. Komunikacja naukowa } 4 / 40 \\
\text { 4. Wyszukiwanie informacji } \\
99 / 100 \\
\text { 5. Teoria informacji } 80 / 100 \\
\text { 6. Obiekty informacyjne } 4 / 5\end{array}$ \\
\hline
\end{tabular}




\begin{tabular}{|c|c|c|c|c|}
\hline 1 & 2 & 3 & 4 & 5 \\
\hline 12 & Cisek S. & $\begin{array}{l}\text { Zachowania } \\
\text { informacyjne - } \\
\text { wybrane aspekty }\end{array}$ & 4 & $\begin{array}{l}\text { 1. Nauka o informacji } 17 / 51 \\
\text { 2. Zarządzanie informacją } 85 / 100 \\
\text { 3. Systemy informacyjne } 9 / 100 \\
\text { 4. Bariery informacyjne } 3 / 29 \\
\text { 5. Zachowania informacyjne } 1 / 29 \\
\text { 6. Potrzeby informacyjne } 6 / 100\end{array}$ \\
\hline 13 & Jasiewicz J. & $\begin{array}{l}\text { Obszary, problemy } \\
\text { i metody badawcze } \\
\text { library } \\
\text { and information } \\
\text { science. Część II }\end{array}$ & 3 & $\begin{array}{l}\text { 1. Nauka o informacji } 19 / 51 \\
\text { 2. Informatologia } 3 / 34 \\
\text { 3. Kompetencje informacyjne } 5 / 57 \\
\text { 4. Czasopisma naukowe } 30 / 100 \\
\text { 5. Bibliometria } 12 / 42 \\
\text { 6. Naukometria } 7 / 13\end{array}$ \\
\hline 14 & Materska K. & $\begin{array}{l}\text { Aktualność koncepcji } \\
\text { zarządzania } \\
\text { informacją w dobie } \\
\text { big data-perspektywa } \\
\text { informatologa }\end{array}$ & 3 & $\begin{array}{l}\text { 1. Informatologia } 6 / 34 \\
\text { 2. Zarządzanie informacją } 2 / 100 \\
\text { 3. Biblioteki akademickie } 58 / 71 \\
\text { 4. Wyszukiwanie informacji } \\
67 / 100 \\
\text { 5. Bibliometria } 21 / 42 \\
\text { 6. Naukometria } 9 / 13\end{array}$ \\
\hline 15 & Cisek S. & $\begin{array}{l}\text { "Metodologia } \\
\text { mieszana” } \\
\text { w badaniach nauki } \\
\text { o informacji } \\
\text { i bibliotekoznawstwa }\end{array}$ & 12 & $\begin{array}{l}\text { 1. Nauka o informacji } 1 / 51 \\
\text { 2. Informatologia } 16 / 34 \\
\text { 3. Użytkownicy informacji } 1 / 25 \\
\text { 4. Zachowania informacyjne } \\
17 / 29 \\
\text { 5. Potrzeby informacyjne } 46 / 100\end{array}$ \\
\hline 16 & Babik W. & $\begin{array}{l}\text { Kultura informacyjna: } \\
\text { spojrzenie z punktu } \\
\text { widzenia ekologii } \\
\text { informacji }\end{array}$ & 8 & $\begin{array}{l}\text { 1. Zarządzanie informacją } 75 / 100 \\
\text { 2. Ekologia informacji } 3 / 21 \\
\text { 3. Środowisko informacyjne } 9 / 21 \\
\text { 4. Kultura informacyjna } 1 / 39 \\
\text { 5. Działalność informacyjna } 6 / 82\end{array}$ \\
\hline 17 & Janiak M. & $\begin{array}{l}\text { Informacja naukowa } \\
\text { w Polsce na } \\
\text { przełomie XX i XXI } \\
\text { wieku: dynamika } \\
\text { zmian w świetle } \\
\text { piśmiennictwa }\end{array}$ & 7 & $\begin{array}{l}\text { 1. Nauka o informacji } 10 / 51 \\
\text { 2. Informatologia } 15 / 34 \\
\text { 3. Czasopisma naukowe } 46 / 100 \\
\text { 4. Teoria informacji } 38 / 100 \\
\text { 5. Działalność informacyjna } 5 / 82\end{array}$ \\
\hline 18 & Skórka S. & $\begin{array}{l}\text { Nowe wyzwania } \\
\text { architektury infor- } \\
\text { macji }\end{array}$ & 4 & $\begin{array}{l}\text { 1. Architektura informacji } 1 / 28 \\
\text { 2. Informatologia } 22 / 34 \\
\text { 3. Procesy informacyjne } 35 / 53 \\
\text { 4. Organizacja informacji } 1 / 17 \\
\text { 5. Przestrzeń informacyjna } 16 / 44\end{array}$ \\
\hline 19 & Tafiłowski P. & $\begin{array}{l}\text { Architektura } \\
\text { informacji jako } \\
\text { problem badawczy } \\
\text { informatologii }\end{array}$ & 4 & $\begin{array}{l}\text { 1. Kompetencje informacyjne } 23 / 57 \\
\text { 2. Architektura informacji } 1 / 28 \\
\text { 3. Wyszukiwanie informacji } 7 / 100 \\
\text { 4. Bariery informacyjne } 16 / 29 \\
\text { 5. Przestrzeń informacyjna } 18 / 44\end{array}$ \\
\hline
\end{tabular}




\begin{tabular}{|c|c|c|c|c|}
\hline 1 & 2 & 3 & 4 & 5 \\
\hline 20 & Batorowska H. & $\begin{array}{l}\text { Konektywizm } \\
\text { w kontekście } \\
\text { kształcenia kompe- } \\
\text { tencji informacyjnych }\end{array}$ & 4 & $\begin{array}{l}\text { 1. Kompetencje informacyjne } 17 / 57 \\
\text { 2. Ekologia informacji } 15 / 21 \\
\text { 3. Zachowania informacyjne } 13 / 29 \\
\text { 4. Kultura informacyjna } 13 / 39 \\
\text { 5. Potrzeby informacyjne } 55 / 100\end{array}$ \\
\hline 21 & Nahotko M. & $\begin{array}{l}\text { Metadane } \\
\text { biblioteczne } \\
\text { XXI wieku }\end{array}$ & 4 & $\begin{array}{l}\text { 1. Biblioteki akademickie } 55 / 71 \\
\text { 2. Komunikacja naukowa } 3 / 40 \\
\text { 3. Wyszukiwanie informacji } 45 / 100 \\
\text { 4. Działalność informacyjna } 12 / 82 \\
\text { 5. Potrzeby informacyjne } 67 / 100\end{array}$ \\
\hline 22 & Jasiewicz J. & $\begin{array}{l}\text { Zachowania } \\
\text { informacyjne } \\
\text { młodzieży a elementy } \\
\text { edukacji informacyj- } \\
\text { nej w Polsce }\end{array}$ & 3 & $\begin{array}{l}\text { 1. Kompetencje informacyjne } 2 / 57 \\
\text { 2. Czasopisma naukowe } 19 / 100 \\
\text { 3. Zachowania informacyjne } 1 / 29 \\
\text { 4. Kultura informacyjna } 16 / 39 \\
\text { 5. Potrzeby informacyjne } 13 / 100\end{array}$ \\
\hline 23 & $\begin{array}{l}\text { Kamińska- } \\
\text {-Czubała B. }\end{array}$ & $\begin{array}{l}\text { Kultura } \\
\text { informacyjna } \\
\text { użytkownika } \\
\text { informacji - proble- } \\
\text { my i metody badań }\end{array}$ & 3 & $\begin{array}{l}\text { 1. Ekologia informacji } 6 / 21 \\
\text { 2. Srodowisko informacyjne } 9 / 21 \\
\text { 3. Kultura informacyjna } 1 / 39 \\
\text { 4. Przestrzeń informacyjna } 3 / 44 \\
\text { 5. Potrzeby informacyjne } 25 / 100\end{array}$ \\
\hline 24 & $\begin{array}{l}\text { Walczak-Nie- } \\
\text { wiadomska A., } \\
\text { Czapnik G., } \\
\text { Gruszka Z. }\end{array}$ & $\begin{array}{l}\text { Brokerstwo } \\
\text { informacyjne } \\
\text { w Polsce - przegląd } \\
\text { publikacji }\end{array}$ & 3 & $\begin{array}{l}\text { 1. Wyszukiwanie informacji } 19 / 100 \\
\text { 2. Teoria informacji } 43 / 100 \\
\text { 3. Użytkownicy informacji } 9 / 25 \\
\text { 4. Infobrokerstwo } 2 / 11 \\
\text { 5. Przestrzeń informacyjna } 32 / 44\end{array}$ \\
\hline
\end{tabular}

\subsection{Wyniki wyszukiwania a zastosowane wyrażenia wyszukiwawcze}

Okazało się, że prace cytowane przynajmniej trzy razy (liczba cytowań po weryfikacji), mające związek z nauką o informacji, stanowią jedynie nieznaczny odsetek wyników wyszukiwania w GS mimo że zastosowano wyrażenia wyszukiwawcze ściśle związane $\mathrm{z}$ tą dyscypliną (Tab. 2). Odsetek takich prac waha się (pomijając jeden przypadek skrajny, który zawierał jedynie dwie pozycje bibliograficzne) od 0.5\% do $9.3 \% \mathrm{w}$ zależności od zastosowanego wyrażenia wyszukiwawczego. Najmniejszy odsetek prac związanych z nauką o informacji uzyskano stosując wyrażenia wyszukiwawcze, które występują także w takich dyscyplinach, jak nauki o zarządzaniu i ekonomia. Prace głównie z tych dyscyplin zdecydowanie dominowały w wynikach wyszukiwania przy zastosowaniu takich terminów jak: zarządzanie informacją, systemy informacyjne, zasoby informacyjne, działalność informacyjna, bezpieczeństwo informacyjne. Największy odsetek prac przyjętych do analizy wyszukano przy zastosowaniu wyrażeń będących albo dwoma nazwami badanej dyscypliny (nauka o informacji, informatologia), albo wyrażeniami wąsko specjalistycznymi (obiekty informacyjne, naukometria, bibliometria, czasopisma open access, zachowania informacyjne, etyka informacyjna). 
Znaczący odsetek wyszukanych prac (wyraźna większość dla każdego terminu, jednakże dokładny procent nie jest istotny dla dalszego wywodu) stanowiły także te, które związane są z nauką o informacji, ale nie uzyskały nawet trzech zweryfikowanych cytowań. Warto przy tym podkreślić, że w przypadku siedmiu spośród czterdziestu wyrażeń wyszukiwawczych nie ma możliwości zapoznania się z kompletem wyników, albowiem GS udostępnia jedynie pierwszy tysiąc pozycji.

W zależności od zastosowanego wyrażenia wyszukiwawczego konieczne okazało się odrzucenie (poza dwoma przypadkami, w których cytowań nie było lub ich suma wynosiła 3 lub mniej) od $7 \%$ do $42 \%$ cytowań z powodów opisanych już powyżej. W ponad połowie przypadków odrzucono więcej niż 20\% cytowań podanych przez Google Scholar.

Tabela 2. Wyniki wyszukiwania za pomocą słów kluczowych dla dyscypliny nauka o informacji

\begin{tabular}{|c|c|c|c|c|c|}
\hline \multirow[b]{2}{*}{ L.p. } & \multirow{2}{*}{$\begin{array}{c}\text { Wyrażenie } \\
\text { wyszukiwawcze }\end{array}$} & \multirow{2}{*}{$\begin{array}{c}\text { Liczba } \\
\text { wyników } \\
\text { w GS (max. } \\
1 \text { tys. widocz- } \\
\text { nych) }\end{array}$} & \multirow{2}{*}{$\begin{array}{l}\text { Liczba prac zakwa- } \\
\text { lifikowanych } \\
\text { do analizy spośród } \\
\text { max. } 1 \text { tys. pozycji } \\
\text { w wynikach } \\
\text { wyszukiwania: } \\
\text { liczba/odsetek } \\
\end{array}$} & \multicolumn{2}{|c|}{$\begin{array}{c}\text { Suma cytowań prac } \\
\text { zakwalifikowanych } \\
\text { do analizy }\end{array}$} \\
\hline & & & & Wg GS & $\begin{array}{l}\text { Po weryfi- } \\
\text { kacji: licz- } \\
\text { ba/odsetek }\end{array}$ \\
\hline 1 & 2 & 3 & 4 & 5 & 6 \\
\hline 1 & Nauka o informacji & 510 & 27 / 5.29\% & 208 & $160 / 76.9 \%$ \\
\hline 2 & Informatologia & 340 & $20 / 5.88 \%$ & 210 & $154 / 73.33 \%$ \\
\hline 3 & Zarządzanie informacją & 2890 & $13 / 1.3 \%$ & 135 & $104 / 77.04 \%$ \\
\hline 4 & Biblioteki akademickie & 709 & $34 / 4.79 \%$ & 277 & 237 / 85.56\% \\
\hline 5 & $\begin{array}{l}\text { Kompetencje } \\
\text { informacyjne }\end{array}$ & 573 & $21 / 3.66 \%$ & 166 & $133 / 80.12 \%$ \\
\hline 6 & Komunikacja naukowa & 400 & $23 / 5.75 \%$ & 280 & $221 / 78.93 \%$ \\
\hline 7 & $\begin{array}{l}\text { Język haseł } \\
\text { przedmiotowych }\end{array}$ & 135 & $1 / 0.74 \%$ & 48 & 35 / 72.92\% \\
\hline 8 & $\begin{array}{l}\text { Rozwój dyscyplin } \\
\text { naukowych }\end{array}$ & 71 & $1 / 1.41 \%$ & 6 & $5 / 83.33 \%$ \\
\hline 9 & $\begin{array}{l}\text { Wyszukiwanie } \\
\text { informacji }\end{array}$ & 1580 & $27 / 2.7 \%$ & 235 & $185 / 78.72 \%$ \\
\hline 10 & $\begin{array}{l}\text { Języki informacyjno- } \\
\text {-wyszukiwawcze }\end{array}$ & 121 & $4 / 3.31 \%$ & 66 & $51 / 77.27 \%$ \\
\hline 11 & $\begin{array}{l}\text { Metody ilościowe } \\
\text { w informatologii }\end{array}$ & 2 & 0 & 0 & 0 \\
\hline 12 & Czasopisma naukowe & 2090 & $21 / 2.1 \%$ & 165 & 117 / 70.91\% \\
\hline 13 & Teoria informacji & 1120 & $25 / 2.5 \%$ & 275 & $204 / 74.18 \%$ \\
\hline 14 & Architektura informacji & 279 & $8 / 2.87 \%$ & 70 & 54 / 77.14\% \\
\hline 15 & Procesy informacyjne & 528 & $9 / 1.7 \%$ & 87 & $72 / 82.76 \%$ \\
\hline
\end{tabular}




\begin{tabular}{|c|c|c|c|c|c|}
\hline 1 & 2 & 3 & 4 & 5 & 6 \\
\hline 16 & Systemy informacyjne & 2840 & $7 / 0.7 \%$ & 34 & $27 / 79.41 \%$ \\
\hline 17 & Zasoby informacyjne & 1340 & $5 / 0.5 \%$ & 57 & 47 / 82.46\% \\
\hline 18 & Ekologia informacji & 205 & $10 / 4.88 \%$ & 80 & $60 / 75 \%$ \\
\hline 19 & Bibliometria & 418 & $25 / 5.98 \%$ & 345 & 239 / 69.27\% \\
\hline 20 & Bariery informacyjne & 288 & $11 / 3.82 \%$ & 97 & 82 / 84.54\% \\
\hline 21 & Użytkownicy informacji & 243 & $11 / 4.53 \%$ & 141 & $98 / 69.5 \%$ \\
\hline 22 & Etyka informacyjna & 20 & $1 / 5 \%$ & 30 & $25 / 83.33 \%$ \\
\hline 23 & $\begin{array}{l}\text { Źródła informacji } \\
\text { naukowej }\end{array}$ & 67 & $1 / 1.49 \%$ & 3 & $3 / 100 \%$ \\
\hline 24 & $\begin{array}{l}\text { Środowisko } \\
\text { informacyjne }\end{array}$ & 202 & $10 / 4.95 \%$ & 73 & $56 / 76.71 \%$ \\
\hline 25 & Organizacja informacji & 167 & $6 / 3.59 \%$ & 119 & $98 / 82.35 \%$ \\
\hline 26 & $\begin{array}{l}\text { Zachowania } \\
\text { informacyjne }\end{array}$ & 287 & $16 / 5.57 \%$ & 197 & $149 / 75.63 \%$ \\
\hline 27 & Kultura informacyjna & 388 & $13 / 3.35 \%$ & 123 & $106 / 86.18 \%$ \\
\hline 28 & $\begin{array}{l}\text { Bibliografia } \\
\text { załącznikowa }\end{array}$ & 188 & $6 / 3.19 \%$ & 62 & 43 / 69.35\% \\
\hline 29 & Wizualizacja informacji & 230 & $4 / 1.74 \%$ & 54 & 35 / 64.81\% \\
\hline 30 & $\begin{array}{l}\text { Bibliograficzna baza } \\
\text { danych }\end{array}$ & 128 & $3 / 2.34 \%$ & 14 & $11 / 78.57 \%$ \\
\hline 31 & $\begin{array}{l}\text { Czasopisma open } \\
\text { access }\end{array}$ & 53 & $3 / 5.66 \%$ & 14 & $13 / 92.86 \%$ \\
\hline 32 & Infobrokerstwo & 102 & $5 / 4.9 \%$ & 33 & $29 / 87.88 \%$ \\
\hline 33 & Biblioteki cyfrowe & 981 & $19 / 1.94 \%$ & 108 & $96 / 88.89 \%$ \\
\hline 34 & Naukometria & 129 & $12 / 9.3 \%$ & 123 & $84 / 68.29 \%$ \\
\hline 35 & $\begin{array}{l}\text { Działalność } \\
\text { informacyjna }\end{array}$ & 819 & $10 / 1.22 \%$ & 143 & $107 / 74.83 \%$ \\
\hline 36 & $\begin{array}{l}\text { Bezpieczeństwo } \\
\text { informacyjne }\end{array}$ & 552 & $2 / 0.36 \%$ & 12 & $10 / 83.33 \%$ \\
\hline 37 & $\begin{array}{l}\text { Reprezentacja i } \\
\text { nformacji }\end{array}$ & 74 & $2 / 2.7 \%$ & 9 & $8 / 88.89 \%$ \\
\hline 38 & Potrzeby informacyjne & 1760 & $15 / 1.5 \%$ & 122 & $95 / 77.87 \%$ \\
\hline 39 & Obiekty informacyjne & 41 & $3 / 7.32 \%$ & 38 & $22 / 57.89 \%$ \\
\hline 40 & $\begin{array}{l}\text { Przestrzeń } \\
\text { informacyjna }\end{array}$ & 435 & $20 / 4.6 \%$ & 172 & $133 / 77.33 \%$ \\
\hline
\end{tabular}




\subsection{Zastosowane wyrażenia wyszukiwawcze a stowa kluczowe towarzyszqce publikacji}

Jedynie słaby związek został potwierdzony przez badanie zgodności wyrażeń wyszukiwawczych wpisywanych do wyszukiwarki Google Scholar ze słowami kluczowymi zamieszczonymi w tytule odszukanej pracy, w metadanych towarzyszących jej tekstowi (w pozycji „słowa kluczowe”), metryce pliku, na stronie WWW wydawcy/czasopisma lub w bibliotece cyfrowej/repozytorium, gdzie plik z tekstem został udostępniony (Tab. 3). Jakakolwiek zgodność wystąpiła w przypadku 12 na 20 prac cytowanych co najmniej dwadzieścia razy lub wyszukanych za pomocą co najmniej siedmiu wyrażeń (bez nazwisk i imion autorów). Sytuacja, w której wszystkie wyrażenia wyszukiwawcze miały swoje odpowiedniki w słowach kluczowych, wystąpiła jedynie w przypadku czterech tekstów odszukanych za pomocą jednego lub dwóch wyrażeń. Jeżeli praca była wyszukana za pomocą większej liczby wyrażeń, to jedynie część z tych wyrażeń miała swoje odpowiedniki w słowach kluczowych: połowa w jednym przypadku, co trzecie (lub ponad 28\%) w trzech przypadkach, co czwarte (lub ponad 22\%) w dwóch przypadkach, a co piąte lub mniej także w dwóch przypadkach. Taki wynik oznacza, że najczęściej wyrażenia, za pomocą których wyszukano daną pracę, nie miały swoich odpowiedników w słowach kluczowych związanych z tym tekstem (74 na 98 rekordów). Na cytowalność pracy oraz na szansę jej wyszukania za pomocą Google Scholar (mierzoną liczbą wyrażeń wyszukiwawczych) nie ma więc istotnego wpływu obudowanie tej pracy słowami kluczowymi (w sposób zgodny z wymaganiami tej wyszukiwarki). W takiej sytuacji nie można uznać, że na ranking wyników wyszukiwania w GS, ustalony cytowaniami, ma wpływ kwestia używania lub nie używania tychże słów kluczowych w języku polskim.

Tabela 3. Związek pomiędzy wyrażeniami wyszukiwawczymi a słowami kluczowymi związanymi z opublikowaną pracą

(Oznaczenia w kolumnie piątej: 1: na stronie WWW wydawcy/czasopisma w opisie publikacji;

2: w metryce pliku PDF; 3: w bibliotece lub repozytorium cyfrowym; 4: w pliku z tekstem pracy).

\begin{tabular}{|c|c|c|c|c|}
\hline L.p. & Autor & Tytuł & Wyrażenia wyszukiwawcze & $\begin{array}{c}\text { Słowa kluczowe w tekście } \\
\text { lub Internecie }\end{array}$ \\
\hline 1 & 2 & 3 & 4 & 5 \\
\hline 1 & Babik W. & $\begin{array}{l}\text { Biblioteka } \\
\text { akademicka } \\
\text { na rozdrożu: } \\
\text { o współ- } \\
\text { czesnych } \\
\text { przemianach } \\
\text { w środowisku } \\
\text { informacyjnym } \\
\text { bibliotek }\end{array}$ & $\begin{array}{l}\text { Biblioteki akademickie } \\
\text { Kompetencje informacyjne } \\
\text { Wyszukiwanie informacji } \\
\text { Teoria informacji } \\
\text { Systemy informacyjne } \\
\text { Środowisko informacyjne } \\
\text { Kultura informacyjna } \\
\text { Przestrzeń informacyjna } \\
\text { Potrzeby informacyjne }\end{array}$ & $\begin{array}{l}\text { 1. brak } \\
\text { 2. brak } \\
\text { 3. biblioteki akademickie, } \\
\text { kultura informacyjna, } \\
\text { społeczeństwo informa- } \\
\text { cyjne, społeczeństwo } \\
\text { oparte na wiedzy } \\
\text { 4. brak }\end{array}$ \\
\hline
\end{tabular}




\begin{tabular}{|c|c|c|c|c|}
\hline 1 & 2 & 3 & 4 & 5 \\
\hline 2 & Babik W. & $\begin{array}{l}\text { Ekologia } \\
\text { informacji } \\
\text { katalizatorem } \\
\text { równoważe- } \\
\text { nia rozwoju } \\
\text { społeczeństwa } \\
\text { informacji } \\
\text { i wiedzy }\end{array}$ & $\begin{array}{l}\text { Zarządzanie informacją } \\
\text { Kompetencje informacyjne } \\
\text { Wyszukiwanie informacji } \\
\text { Procesy informacyjne } \\
\text { Ekologia informacji } \\
\text { Bariery informacyjne } \\
\text { Użytkownicy informacji } \\
\text { Środowisko informacyjne } \\
\text { Zachowania informacyjne } \\
\text { Przestrzeń informacyjna } \\
\text { Potrzeby informacyjne }\end{array}$ & $\begin{array}{l}\text { 1. brak } \\
\text { 2. ekologia informacji; antro- } \\
\text { poinfosfera; zrównoważo- } \\
\text { ny rozwój; społeczeństwo } \\
\text { informacji i wiedzy; nad- } \\
\text { miar informacji; bariery } \\
\text { informacyjne; informacja } \\
\text { ekologiczna } \\
\text { 3. brak } \\
\text { 4. ekologia informa- } \\
\text { cji, antropoinfosfera, } \\
\text { zrównoważony rozwój, } \\
\text { społeczeństwo infor- } \\
\text { macji i wiedzy, nadmiar } \\
\text { informacji, bariery in- } \\
\text { formacyjne, informacja } \\
\text { ekologiczna }\end{array}$ \\
\hline 3 & Babik W. & $\begin{array}{l}\text { Słowa } \\
\text { kluczowe }\end{array}$ & $\begin{array}{l}\text { Język haseł przedmiotowych } \\
\text { Języki informacyjno-wyszu- } \\
\text { kiwawcze } \\
\text { Teoria informacji } \\
\text { Organizacja informacji } \\
\text { Działalność informacyjna } \\
\text { Przestrzeń informacyjna }\end{array}$ & $\begin{array}{l}\text { 1. informacja naukowa, } \\
\text { termin, systemy wy- } \\
\text { szukiwania informacji, } \\
\text { bibliotekoznawstwo, } \\
\text { słowa kluczowe } \\
\text { 2. keywords; information } \\
\text { retrieval; indexing; } \\
\text { Internet; information } \\
\text { organization; indexing } \\
\text { and retrieval languages; } \\
\text { documentary indexing } \\
\text { and retrieval system } \\
\text { 3. brak } \\
\text { 4. brak }\end{array}$ \\
\hline 4 & $\begin{array}{l}\text { Batorow- } \\
\text { ska H. }\end{array}$ & $\begin{array}{l}\text { Od alfabetyza- } \\
\text { cji informacyj- } \\
\text { nej do kultury } \\
\text { informacyjnej: } \\
\text { rozważania } \\
\text { o dojrzałości } \\
\text { informacyjnej }\end{array}$ & $\underline{\text { Kultura informacyjna }}$ & $\begin{array}{l}\text { 1. kultura, społeczeństwo } \\
\text { informacyjne } \\
\text { 2. brak } \\
\text { 3. brak } \\
\text { 4. brak }\end{array}$ \\
\hline 5 & $\begin{array}{l}\text { Batorow- } \\
\text { ska H., } \\
\text { Klepka R., } \\
\text { Wasiuta O. }\end{array}$ & $\begin{array}{l}\text { Media jako } \\
\text { instrument } \\
\text { wpływu } \\
\text { informacyjnego } \\
\text { i manipulacji } \\
\text { społeczeń- } \\
\text { stwem }\end{array}$ & $\begin{array}{l}\text { Nauka o informacji } \\
\text { Kompetencje informacyjne } \\
\text { Teoria informacji } \\
\text { Procesy informacyjne } \\
\text { Ekologia informacji } \\
\text { Wyszukiwanie informacji } \\
\text { Architektura informacji } \\
\text { Bariery informacyjne } \\
\text { Użytkownicy informacji } \\
\text { Bezpieczeństwo informacyjne }\end{array}$ & $\begin{array}{l}\text { 1. brak } \\
\text { 2. media, manipulacja, } \\
\text { wpływ polityczny, } \\
\text { media, politics, media } \\
\text { influence, media mani- } \\
\text { pulations } \\
\text { 3. brak } \\
\text { 4. brak }\end{array}$ \\
\hline
\end{tabular}




\begin{tabular}{|c|c|c|c|c|}
\hline 1 & 2 & 3 & 4 & 5 \\
\hline 6 & $\begin{array}{l}\text { Błocki Z., } \\
\text { Życzkow- } \\
\text { ski K. }\end{array}$ & $\begin{array}{l}\text { Czy można } \\
\text { porównywać } \\
\text { jabłka i grusz- } \\
\text { ki? O danych } \\
\text { bibliometrycz- } \\
\text { nych w różnych } \\
\text { dziedzinach } \\
\text { nauki }\end{array}$ & Bibliometria & $\begin{array}{l}\text { 1. brak } \\
\text { 2. brak } \\
\text { 3. brak } \\
\text { 4. brak }\end{array}$ \\
\hline 7 & Cisek S. & $\begin{array}{l}\text { Metoda analizy } \\
\text { i krytyki } \\
\text { piśmiennic- } \\
\text { twa w nauce } \\
\text { o informacji } \\
\text { i biblioteko- } \\
\text { znawstwie } \\
\text { w XXI wieku }\end{array}$ & $\begin{array}{l}\text { Nauka o informacji } \\
\text { Informatologia } \\
\text { Zarządzanie informacją } \\
\text { Biblioteki akademickie } \\
\text { Komunikacja naukowa } \\
\text { Bibliometria } \\
\text { Zachowania informacyjne }\end{array}$ & $\begin{array}{l}\text { 1. analiza i krytyka pi- } \\
\text { śmiennictwa; badania } \\
\text { literaturowe; biblioteko- } \\
\text { znawstwo; informatolo- } \\
\text { gia; nauka o informacji; } \\
\text { metaanaliza; metodo- } \\
\text { logia; metody badań; } \\
\text { przegląd systematyczny; } \\
\text { stan badań; XXI wiek } \\
\text { 2. brak } \\
\text { 3. brak } \\
\text { 4. brak }\end{array}$ \\
\hline 8 & Jasiewicz J. & $\begin{array}{l}\frac{\text { Kompetencje }}{\text { informacyjne }} \\
\text { młodzieży: } \\
\text { analiza-stan } \\
\text { faktyczny- } \\
\text {-kształcenie } \\
\text { na przykładzie } \\
\text { Polski, Nie- } \\
\text { miec i Wielkiej } \\
\text { Brytanii }\end{array}$ & $\underline{\text { Kompetencje informacyjne }}$ & $\begin{array}{l}\text { 1. brak } \\
\text { 2. brak } \\
\text { 3. informacja cyfrowa; } \\
\text { media masowe - eduka- } \\
\text { cja; nowe technologie; } \\
\text { społeczeństwo informa- } \\
\text { cyjne } \\
\text { 4. brak }\end{array}$ \\
\hline 9 & Jasiewicz J. & $\begin{array}{l}\text { Obszary, pro- } \\
\text { blemy i metody } \\
\text { badawcze } \\
\text { library and } \\
\text { information } \\
\text { science. Część I }\end{array}$ & $\begin{array}{l}\text { Nauka o informacji } \\
\text { Informatologia } \\
\text { Biblioteki akademickie } \\
\text { Kompetencje informacyjne } \\
\text { Wyszukiwanie informacji } \\
\text { Teoria informacji } \\
\text { Systemy informacyjne } \\
\text { Bibliometria } \\
\text { Zachowania informacyjne }\end{array}$ & $\begin{array}{l}\text { 1. brak } \\
\text { 2. brak } \\
\text { 3. brak } \\
\text { 4. bibliologia i informa- } \\
\text { tologia, library and } \\
\text { information science, ob- } \\
\text { szary badawcze, metody } \\
\text { badawcze, bibliometria }\end{array}$ \\
\hline 10 & $\begin{array}{l}\text { Kisilow- } \\
\text { ska M. }\end{array}$ & $\begin{array}{l}\text { Przestrzeń } \\
\text { informacyjna } \\
\text { jako termin } \\
\text { informatolo- } \\
\text { giczny }\end{array}$ & $\begin{array}{l}\text { Kompetencje informacyjne } \\
\text { Teoria informacji } \\
\text { Ekologia informacji } \\
\text { Środowisko informacyjne } \\
\text { Zachowania informacyjne } \\
\text { Działalność informacyjna } \\
\text { Przestrzeń informacyjna }\end{array}$ & $\begin{array}{l}\text { 1. brak } \\
\text { 2. brak } \\
\text { 3. brak } \\
\text { 4. przestrzeń informacyj- } \\
\text { na, środowisko informa- } \\
\text { cyjne, infosfera }\end{array}$ \\
\hline
\end{tabular}




\begin{tabular}{|c|c|c|c|c|}
\hline 1 & 2 & 3 & 4 & 5 \\
\hline 11 & $\begin{array}{l}\text { Klince- } \\
\text { wicz K., } \\
\text { Mijal M., } \\
\text { Żemiga- } \\
\text { ła M. }\end{array}$ & $\begin{array}{l}\text { Bibliometria } \\
\text { w zarządzaniu } \\
\text { technologiami } \\
\text { i badaniami } \\
\text { naukowymi. }\end{array}$ & $\underline{\text { Bibliometria }}$ & $\begin{array}{l}\text { 1. brak } \\
\text { 2. brak } \\
\text { 3. bibliometria } \\
\text { 4. brak }\end{array}$ \\
\hline 12 & $\begin{array}{l}\text { Kola- } \\
\text { sa W.M. }\end{array}$ & $\begin{array}{l}\text { Historiografia } \\
\text { prasy polskiej } \\
\text { (do } 1918 \text { roku): } \\
\text { naukome- } \\
\text { tryczna analiza } \\
\text { dyscypliny } \\
\text { 1945-2009 }\end{array}$ & $\begin{array}{l}\text { Bibliometria } \\
\text { Naukometria }\end{array}$ & $\begin{array}{l}\text { 1. brak } \\
\text { 2. brak } \\
\text { 3. historiography, history } \\
\text { of the press, research, } \\
\text { Poland, citation analysis, } \\
\text { scientometrics, } \\
\text { bibliometrics, } \\
\text { historiografia, historia } \\
\text { prasy, badania, Polska, } \\
\text { analiza cytowań, } \\
\text { naukometria, } \\
\text { bibliometria }\end{array}$ \\
\hline 13 & Kulczycki E. & $\begin{array}{l}\text { Wykorzystanie } \\
\text { mediów } \\
\text { społecznościo- } \\
\text { wych przez } \\
\text { akademickie } \\
\text { uczelnie wyż- } \\
\text { sze w Polsce. } \\
\text { Badania w for- } \\
\text { mule otwartego } \\
\text { notatnika. }\end{array}$ & Komunikacja naukowa & $\begin{array}{l}\text { 1. brak } \\
\text { 2. Social Media, Open } \\
\text { Science, Blog, Blogging, } \\
\text { Blogosphere, Science, } \\
\text { Communication, } \\
\text { University } \\
\text { 3. brak } \\
\text { 4. brak }\end{array}$ \\
\hline 14 & Nahotko M. & $\begin{array}{l}\text { Komunika- } \\
\text { cja naukowa } \\
\text { w środowisku } \\
\text { cyfrowym: glo- } \\
\text { balna biblioteka } \\
\text { cyfrowa w in- } \\
\text { formatycznej } \\
\text { infrastrukturze } \\
\text { nauki }\end{array}$ & $\begin{array}{l}\text { Komunikacja naukowa } \\
\text { Wyszukiwanie informacji } \\
\text { Użytkownicy informacji } \\
\text { Organizacja informacji }\end{array}$ & $\begin{array}{l}\text { 1. informacja naukowa - } \\
\text { technologia, biblioteki } \\
\text { cyfrowe } \\
\text { 2. brak } \\
\text { 3. brak } \\
\text { 4. brak }\end{array}$ \\
\hline 15 & $\begin{array}{l}\text { Pamuła- } \\
\text {-Cieślak N. }\end{array}$ & $\begin{array}{l}\text { Ukryty Internet } \\
\text { jako przedmiot } \\
\text { edukacji } \\
\text { informacyjnej }\end{array}$ & $\begin{array}{l}\text { Biblioteki akademickie } \\
\text { Komunikacja naukowa } \\
\text { Wyszukiwanie informacji } \\
\text { Teoria informacji } \\
\text { Bariery informacyjne } \\
\text { Kultura informacyjna } \\
\text { Przestrzeń informacyjna }\end{array}$ & $\begin{array}{l}\text { 1. brak } \\
\text { 2. brak } \\
\text { 3. brak } \\
\text { 4. brak }\end{array}$ \\
\hline
\end{tabular}




\begin{tabular}{|c|c|c|c|c|}
\hline 1 & 2 & 3 & 4 & 5 \\
\hline 16 & $\begin{array}{l}\text { Sapa R., } \\
\text { Krakow- } \\
\text { ska M., } \\
\text { Janiak M. }\end{array}$ & $\begin{array}{l}\text { Information se- } \\
\text { eking behaviour } \\
\text { of mathemati- } \\
\text { cians: scientists } \\
\text { and students }\end{array}$ & Zachowania informacyjne & $\begin{array}{l}\text { 1. brak } \\
\text { 2. brak } \\
\text { 3. brak } \\
\text { 4. brak }\end{array}$ \\
\hline 17 & $\begin{array}{l}\text { Sosińska- } \\
\text {-Kalata B. }\end{array}$ & $\begin{array}{l}\text { Obszary badań } \\
\text { współczesnej } \\
\text { informatologii } \\
\text { (nauki o infor- } \\
\text { macji) }\end{array}$ & $\begin{array}{l}\text { Nauka o informacji } \\
\text { Informatologia } \\
\text { Kompetencje informacyjne } \\
\text { Komunikacja naukowa } \\
\text { Wyszukiwanie informacji } \\
\text { Procesy informacyjne } \\
\text { Bibliometria } \\
\text { Etyka informacyjna } \\
\text { Zachowania informacyjne } \\
\text { Działalność informacyjna }\end{array}$ & $\begin{array}{l}\text { 1. Informatologia. } \\
\text { Definicje. Interdy- } \\
\text { scyplinarność. Nauka } \\
\text { o informacji. Nurty ba- } \\
\text { dawcze. Pole badawcze. } \\
\text { Problemy badawcze } \\
\text { 2. brak } \\
\text { 3. brak } \\
\text { 4. Informatologia. } \\
\text { Definicje. Interdy- } \\
\text { scyplinarność. Nauka } \\
\text { o informacji. Nurty ba- } \\
\text { dawcze. Pole badawcze. } \\
\text { Problemy badawcze }\end{array}$ \\
\hline 18 & Świgoń M. & $\begin{array}{l}\text { Information } \\
\text { barriers in } \\
\text { libraries: types, } \\
\text { typologies and } \\
\text { Polish empiri- } \\
\text { cal studies }\end{array}$ & Bariery informacyjne & $\begin{array}{l}\text { 1. Information manage- } \\
\text { ment, Libraries, } \\
\text { Barriers, Anxiety } \\
\text { 2. brak } \\
\text { 3. brak } \\
\text { 4. Information manage- } \\
\text { ment, Libraries, Bar- } \\
\text { riers, Anxiety }\end{array}$ \\
\hline 19 & $\begin{array}{l}\text { Wojcie- } \\
\text { chowski J. }\end{array}$ & $\begin{array}{l}\text { Biblioteka } \\
\text { w komunikacji } \\
\text { publicznej }\end{array}$ & Biblioteki akademickie & $\begin{array}{l}\text { 1. biblioteki publiczne } \\
\text { 2. brak } \\
\text { 3. brak } \\
\text { 4. brak }\end{array}$ \\
\hline 20 & $\begin{array}{l}\text { Woźniak- } \\
\text {-Kasperek J. }\end{array}$ & $\begin{array}{l}\text { Języki } \\
\text { informacyjne: } \\
\text { między tradycją } \\
\text { a nadzieją na } \\
\text { cyfrową } \\
\text { przyszłość }\end{array}$ & $\begin{array}{l}\text { Nauka o informacji } \\
\text { Biblioteki akademickie } \\
\text { Kompetencje informacyjne } \\
\text { Wyszukiwanie informacji } \\
\text { Architektura informacji } \\
\text { Użytkownicy informacji } \\
\text { Srodowisko informacyjne } \\
\text { Obiekty informacyjne }\end{array}$ & $\begin{array}{l}\text { 1. brak } \\
\text { 2. brak } \\
\text { 3. brak } \\
\text { 4. Ilość informacji. } \\
\text { Integracja zasobów } \\
\text { informacyjnych. Inte- } \\
\text { gracja wyszukiwania. } \\
\text { Język informacyjno-wy- } \\
\text { szukiwawczy. Obiekt } \\
\text { informacyjny. Sieć. Śro- } \\
\text { dowisko informacyjne. } \\
\text { Użytkownicy informacji. } \\
\text { Wyszukiwanie } \\
\text { informacji. Zmiana }\end{array}$ \\
\hline
\end{tabular}




\section{Wnioski}

Zastosowana metodologia ma pewne ograniczenia. Firma Google nie ujawnia wszystkich mechanizmów i algorytmów odpowiedzialnych za tworzenie listy wyników w odpowiedzi na określone wyrażenie wyszukiwawcze oraz za porządkowanie wyników. W związku z tym trudno o jednoznaczne określenie powodów, dla których czasami stosunkowo często cytowane publikacje w języku polskim umieszczane są na początku listy wyników, a czasami na bardzo dalekich pozycjach. Podobnie trudno o jednoznaczne wyjaśnienie zjawiska polegającego na tym, że dana praca pojawia się na liście wyników w odpowiedzi na zastosowanie wyrażenia wyszukiwawczego, które nie jest tożsame ze słowami kluczowymi zawartymi w metadanych tej pracy. Trzecie zjawisko, które trudno jednoznacznie wyjaśnić, polega na tym, że na liście wyników związanej z wyrażeniem wyszukiwawczym w języku polskim pojawia się praca w języku angielskim (informacje od wydawcy na stronie WWW także są po angielsku). Sytuacja taka dotyczyła jednak jedynie nielicznych publikacji. Z kolei wątpliwość dotycząca odsetka prac polskich autorów opublikowanych w języku angielskim, które nie zostały wykazane w wynikach wyszukiwania przy zastosowaniu wyrażenia wyszukiwawczego w języku polskim, znalazła jednak swoje wyjaśnienie po zastosowaniu wyrażeń wyszukiwawczych w postaci imion i nazwisk tych autorów, o czym już wspomniano omawiając wyniki badań. Publikacje w języku angielskim, pominięte ze względu na stosowanie wyrażeń wyszukiwawczych w języku polskim, to ok. 10\% ogólnej liczby prac uwzględnionych w badaniach.

Przeprowadzone za pomocą GS wyszukiwanie prac z zakresu nauki o informacji wykazało, że w przypadku wyrażeń wyszukiwawczych w języku polskim nie znajduje potwierdzenia teza Stribu et al. (2015) mówiąca, iż ta wyszukiwarka nadaje się do niezawodnej identyfikacji najczęściej cytowanych prac i badaczy. Okazało się bowiem, że algorytmy decydujące o doborze prac do danego wyrażenia wyszukiwawczego oraz porządkujące wyniki wyszukiwania w przypadku użycia języka polskiego są wysoce zawodne. Znacząca statystycznie część prac indeksowanych w GS nie pojawia się w wynikach, gdy wyszukiwanie przeprowadza się na podstawie słów kluczowych fundamentalnych dla nauki o informacji. Publikacje te zostają wyszukane dopiero wtedy, gdy wyrażeniem wyszukiwawczym jest imię i nazwisko autora. Jeszcze większa grupa tekstów stosunkowo często cytowanych umieszczona jest na bardzo dalekich miejscach w wynikach wyszukiwania, co powoduje, że niewielu szukających do nich dotrze. Nie można ustalić, jakie prace GS umieszcza powyżej tysięcznej pozycji w wynikach wyszukiwania. Nie znajduje także potwierdzenia teza Martina-Martina et al. (2017) mówiąca, że głównym kryterium porządkowania wyników wyszukiwania jest liczba cytowań wyszukanych prac. Okazało się bowiem, że znacząca statystycznie grupa prac w języku polskim, stosunkowo często cytowanych, znajduje się dopiero w trzecim i czwartym kwartylu wyników wyszukiwania.

Stwierdzono też, że zdecydowana większość publikacji wskazanych w wynikach wyszukiwania nie jest adekwatna do intencji wyszukującego. GS nie odróżnia bowiem prac pochodzących z różnych dyscyplin naukowych, które co prawda stosują niekiedy identyczne słowa kluczowe, ale zakres ich badań i treść artykułów jest znacząco różna. Ponadto, wyszukiwarka GS nie dość dobrze profiluje zainteresowania użytkownika. Uwagę tę należy umieścić w kontekście faktu, że prawie każda wyszukiwarka zapisuje aktywność każdego adresu IP i profiluje użytkownika korzystającego z urządzenia, któremu ten adres jest 
przyporządkowany. Autor niniejszej pracy przez kilka miesięcy korzystał z tego samego komputera, był zalogowany na konto Google i w tym czasie w GS wpisywał jedynie hasła związane z nauką o informacji. W wynikach wyszukiwania korzystał jedynie z informacji na temat prac, które zakwalifikował jako przynależne do tej dyscypliny. Najwyraźniej GS nie stworzyło właściwego profilu zainteresowań autora, albowiem relewancja wyników pod koniec badań była na podobnym poziomie jak na początku.

Wyszukiwarka GS nie odróżnia też prac naukowych od innych materiałów zamieszczonych w zasobach indeksowanych przez własne roboty internetowe. Znaczącą statystycznie część cytowań przypisanych każdej prawie pracy trudno uznać za świadczącą o poziomie wpływu tej pracy na rozwój badań. Są to bowiem autocytowania, duplikaty cytowań, cytowania pochodzące ze źródeł innych niż opublikowana praca naukowa oraz różne błędy.

Tak więc pojawienie się tekstu w wynikach wyszukiwania nie oznacza, że ma on związek z intencjami wyszukującego, wyrażonymi za pomocą określonych terminów wyszukiwawczych i dotychczasowymi poszukiwaniami w zasobach indeksowanych przez GS, a towarzysząca mu informacja o liczbie cytowań nie zawsze oznacza, że tyle właśnie cytowań zdobyła ta praca. Doszukiwanie się związku pomiędzy liczbą cytowań pracy podawaną przez GS, a jej popularnością (bo o jakości nie można wyrokować na podstawie cytowań), zbyt często wiedzie na manowce.

W świetle przeprowadzonych badań można stwierdzić, że czynnikiem wpływającym w sposób zauważalny na kolejność prac w wynikach wyszukiwania raczej nie jest dobór słów kluczowych towarzyszących danej pracy. Autor tekstu i jego wydawca, dzięki właściwemu zastosowaniu słów kluczowych, nie zwiększają szansy na wyszukanie tego tekstu w GS za pomocą polskich wyrażeń wyszukiwawczych. Teza o tym, że możliwe jest opracowanie zasad optymalizacji pod kątem uzyskania przez daną pracę miejsca na pierwszych stronach wyników, w których to zasadach kluczowe będzie odpowiednie użycie słów kluczowych (Beel et al., 2010), jest prawdziwa w sytuacji używania języka angielskiego, ale mocno wątpliwa w przypadku języka polskiego. Przeprowadzone badanie nie dało odpowiedzi na pytanie, co zwiększa szanse tekstu naukowego na odnalezienie go w Internecie przez potencjalnie zainteresowanego, polskiego czytelnika. Nie wpływa na to ani cytowalność pracy, ani zabiegi autora i wydawców związane z wyborem słów kluczowych. Także stosowanie wyrażeń wyszukiwawczych będących terminami kluczowymi dla nauki o informacji oraz przeglądanie więcej niż kilku pierwszych stron wyników wyszukiwania nie daje gwarancji odnalezienia każdego tekstu tematycznie związanego z danym terminem, nawet jeżeli uzyskał on stosunkowo dużą liczbę cytowań.

Wobec tego sugestie, o tym że Google Scholar można profesjonalnie (np. w celach badawczych) wykorzystywać do wyszukiwania najbardziej popularnych (czyli stosunkowo często cytowanych) prac naukowych oraz do formułowania ocen (bazujących na cytowaniach) tychże prac opublikowanych w języku polskim i badaczy publikujących głównie w tym języku, w realiach nauki o informacji zbyt często okazują się błędne. 


\section{Załącznik 1. Ranking prac, które uzyskały przynajmniej 10 zweryfikowanych cytowań}

W ostatniej kolumnie informacja „Autor” - pozycja znaleziona, gdy wyrażeniem wyszukiwawczym było imię i nazwisko autora plus ograniczenie wyników do języka polskiego; „Autor ang." - brak ograniczenia wyników do języka polskiego.

\begin{tabular}{|c|c|c|c|c|c|c|}
\hline L.p. & Autor & Tytuł & $\begin{array}{c}\text { Czasopismo/ } \\
\text { Praca } \\
\text { zbiorowa }\end{array}$ & $\begin{array}{l}\text { Rok } \\
\text { pu- } \\
\text { bli- } \\
\text { kacji }\end{array}$ & $\begin{array}{l}\text { Liczba } \\
\text { zwery- } \\
\text { fikowa- } \\
\text { nych } \\
\text { cyto- } \\
\text { wań }\end{array}$ & $\begin{array}{c}\text { Wyrażenia } \\
\text { wyszukiwawcze } \\
\text { i strona w wyni- } \\
\text { kach/liczba stron }\end{array}$ \\
\hline 1 & 2 & 3 & 4 & 5 & 6 & 7 \\
\hline 1 & $\begin{array}{l}\text { Nicholas } \\
\text { D., Bouka- } \\
\text { cem-Zegh- } \\
\text { mouri Ch., } \\
\text { Rodríguez- } \\
\text {-Bravo B., Xu } \\
\text { J., Watkinson } \\
\text { A., Abrizah } \\
\text { A., Herman E., } \\
\text { Świgoń M. }\end{array}$ & $\begin{array}{l}\text { Where and how } \\
\text { early career } \\
\text { researchers find } \\
\text { scholarly } \\
\text { information }\end{array}$ & $\begin{array}{l}\text { Learned } \\
\text { Publishing }\end{array}$ & 2017 & 57 & Autor ang. \\
\hline 2 & $\begin{array}{l}\text { Nicholas D., } \\
\text { Rodríguez- } \\
\text {-Bravo B., } \\
\text { Boukacem- } \\
\text {-Zeghmo- } \\
\text { uri Ch., } \\
\text { Rodríguez- } \\
\text {-Bravo B., Xu } \\
\text { J., Watkinson } \\
\text { A., Abrizah } \\
\text { A., Herman E., } \\
\text { Swigoń M. } \\
\end{array}$ & $\begin{array}{l}\text { Early career } \\
\text { researchers } \\
\text { and their } \\
\text { publishing } \\
\text { and authorship } \\
\text { practices }\end{array}$ & $\begin{array}{l}\text { Learned } \\
\text { Publishing }\end{array}$ & 2017 & 50 & Autor ang. \\
\hline 3 & Świgoń M. & $\begin{array}{l}\text { Library anxiety } \\
\text { among Polish } \\
\text { students: Develop- } \\
\text { ment and validation } \\
\text { of the Polish Libra- } \\
\text { ry Anxiety Scale }\end{array}$ & $\begin{array}{l}\text { Library } \\
\text { E Informa- } \\
\text { tion Science } \\
\text { Research }\end{array}$ & 2011 & 44 & Autor ang. \\
\hline 4 & Batorowska H. & $\begin{array}{l}\text { Od alfabetyzacji } \\
\text { informacyjnej do kul- } \\
\text { tury informacyjnej: } \\
\text { rozważania o dojrza- } \\
\text { tości informacyjnej }\end{array}$ & & 2013 & 43 & $\begin{array}{l}\text { Kultura informa- } \\
\text { cyjna } 1 / 39\end{array}$ \\
\hline
\end{tabular}




\begin{tabular}{|c|c|c|c|c|c|c|}
\hline 1 & 2 & 3 & 4 & 5 & 6 & 7 \\
\hline 5 & $\begin{array}{l}\text { Klincewicz K., } \\
\text { Mijal M., } \\
\text { Żemigała M. }\end{array}$ & $\begin{array}{l}\text { Bibliometria } w \text { za- } \\
\text { rzadzaniu technolo- } \\
\text { giami i badaniami } \\
\text { naukowymi }\end{array}$ & & 2012 & 40 & Bibliometria $1 / 42$ \\
\hline 6 & Nahotko M. & $\begin{array}{l}\text { Komunikacja } \\
\text { naukowa } \\
\text { w środowisku } \\
\text { cyfrowym: globalna } \\
\text { biblioteka cyfrowa } \\
\text { w informatycznej } \\
\text { infrastrukturze } \\
\text { nauki }\end{array}$ & & 2010 & 40 & $\begin{array}{l}\text { Komunikacja } \\
\text { naukowa } 1 / 40 \\
\text { Wyszukiwanie } \\
\text { informacji } 61 / 100 \\
\text { Użytkownicy } \\
\text { informacji } 23 / 25 \\
\text { Organizacja infor- } \\
\text { macji 14/17 }\end{array}$ \\
\hline 7 & $\begin{array}{l}\text { Wojciechow- } \\
\text { ski J. }\end{array}$ & $\begin{array}{l}\text { Biblioteka w komu- } \\
\text { nikacji publicznej }\end{array}$ & & 2010 & 40 & $\begin{array}{l}\text { Biblioteki akade- } \\
\text { mickie 61/71 }\end{array}$ \\
\hline 8 & $\begin{array}{l}\text { Nicholas D., } \\
\text { Rodríguez- } \\
\text {-Bravo B., } \\
\text { Boukacem- } \\
\text {-Zeghmo- } \\
\text { uri Ch., } \\
\text { Rodríguez- } \\
\text {-Bravo B., Xu } \\
\text { J., Watkinson } \\
\text { A., Abrizah } \\
\text { A., Herman E., } \\
\text { Ŝwigoń M. } \\
\end{array}$ & $\begin{array}{l}\text { Early career rese- } \\
\text { archers: Scholarly } \\
\text { behaviour and the } \\
\text { prospect of change }\end{array}$ & $\begin{array}{l}\text { Learned } \\
\text { Publishing }\end{array}$ & 2017 & 36 & Autor ang. \\
\hline 9 & Babik W. & Stowa kluczowe & & 2010 & 35 & $\begin{array}{l}\text { Język haseł przed- } \\
\text { miotowych } 9 / 14 \\
\text { Języki informacyj- } \\
\text { no-wyszukiwaw- } \\
\text { cze } 9 / 12 \\
\text { Teoria informacji } \\
60 / 100 \\
\text { Organizacja infor- } \\
\text { macji } 7 / 17 \\
\text { Działalność infor- } \\
\text { macyjna } 68 / 82 \\
\text { Przestrzeń infor- } \\
\text { macyjna } 38 / 44\end{array}$ \\
\hline 10 & Gmiterek G. & $\begin{array}{l}\text { Biblioteka w środo- } \\
\text { wisku spoteczno- } \\
\text { ściowego Internetu: } \\
\text { biblioteka } 2.0\end{array}$ & & 2012 & 33 & Autor \\
\hline 11 & $\begin{array}{l}\text { Woźniak- } \\
\text { Kasperek J. }\end{array}$ & $\begin{array}{l}\text { Wiedza i język infor- } \\
\text { macyjny w paradyg- } \\
\text { macie sieciowym }\end{array}$ & & 2011 & 32 & Autor \\
\hline
\end{tabular}




\begin{tabular}{|c|c|c|c|c|c|c|}
\hline 1 & 2 & 3 & 4 & 5 & 6 & 7 \\
\hline 12 & Kolasa W.M. & $\begin{array}{l}\text { Historiografia prasy } \\
\text { polskiej (do } 1918 \\
\text { roku): naukome- } \\
\text { tryczna analiza dys- } \\
\text { cypliny 1945-2009 }\end{array}$ & & 2013 & 30 & $\begin{array}{l}\text { Bibliometria } \\
14 / 42 \\
\text { Naukometria } \\
9 / 13\end{array}$ \\
\hline 13 & Świgoń M. & $\begin{array}{l}\text { Information bar- } \\
\text { riers in libraries: } \\
\text { types, typologies } \\
\text { and Polish empiri- } \\
\text { cal studies }\end{array}$ & $\begin{array}{l}\text { Library } \\
\text { Management }\end{array}$ & 2011 & 27 & $\begin{array}{l}\text { Bariery informa- } \\
\text { cyjne } 10 / 29\end{array}$ \\
\hline 14 & $\begin{array}{l}\text { Wojciechow- } \\
\text { ski J. }\end{array}$ & $\begin{array}{l}\text { Biblioteki w nowym } \\
\text { otoczeniu }\end{array}$ & & 2014 & 27 & Autor \\
\hline 15 & $\begin{array}{l}\text { Sapa R., Kra- } \\
\text { kowska M., } \\
\text { Janiak M. }\end{array}$ & $\begin{array}{l}\text { Information } \\
\text { seeking behaviour } \\
\text { of mathematicians: } \\
\text { scientists } \\
\text { and students }\end{array}$ & $\begin{array}{l}\text { Information } \\
\text { Research }\end{array}$ & 2014 & 25 & $\begin{array}{l}\text { Zachowania in- } \\
\text { formacyjne } 26 / 29\end{array}$ \\
\hline 16 & $\begin{array}{l}\text { Sosińska- } \\
\text { Kalata B. }\end{array}$ & $\begin{array}{l}\text { Obszary badań } \\
\text { współczesnej } \\
\text { informatologii } \\
\text { (nauki o informacji) }\end{array}$ & $\begin{array}{l}\text { Zagadnienia } \\
\text { Informacji } \\
\text { Naukowej }\end{array}$ & 2013 & 25 & $\begin{array}{l}\text { Nauka o informa- } \\
\text { cji } 1 / 51 \\
\text { Informatologia } \\
19 / 34 \\
\text { Kompetencje } \\
\text { informacyjne } \\
33 / 57 \\
\text { Komunikacja } \\
\text { naukowa } 16 / 40 \\
\text { Wyszukiwanie } \\
\text { informacji } 3 / 100 \\
\text { Procesy informa- } \\
\text { cyjne } 37 / 53 \\
\text { Bibliometria } \\
18 / 42 \\
\text { Etyka informacyj- } \\
\text { na } 2 / 2 \\
\text { Zachowania in- } \\
\text { formacyjne } 15 / 29 \\
\text { Działalność infor- } \\
\text { macyjna } 12 / 82\end{array}$ \\
\hline 17 & Świgoń M. & $\begin{array}{l}\text { Personal knowledge } \\
\text { and information } \\
\text { management-con- } \\
\text { ception and exem- } \\
\text { plification }\end{array}$ & $\begin{array}{l}\text { Journal of } \\
\text { Information } \\
\text { Science }\end{array}$ & 2013 & 25 & Autor ang. \\
\hline
\end{tabular}




\begin{tabular}{|c|c|c|c|c|c|c|}
\hline 1 & 2 & 3 & 4 & 5 & 6 & 7 \\
\hline 18 & Jasiewicz J. & $\begin{array}{l}\text { Kompetencje infor- } \\
\text { macyjne młodzie- } \\
\dot{z} y: \text { analiza-stan } \\
\text { faktyczny-kształce- } \\
\text { nie na przyktadzie } \\
\text { Polski, Niemiec } \\
i \text { Wielkiej Brytanii }\end{array}$ & & 2012 & 24 & $\begin{array}{l}\text { Kompetencje in- } \\
\text { formacyjne } 1 / 57\end{array}$ \\
\hline 19 & Świgoń M. & $\begin{array}{l}\text { Zarzadzanie } \\
\text { wiedza i informacja. } \\
\text { Podstawy teore- } \\
\text { tyczne. Badania } \\
\text { w wymiarze indywi- } \\
\text { dualnym }\end{array}$ & & 2012 & 24 & Autor \\
\hline 20 & $\begin{array}{l}\text { Błocki Z., } \\
\text { Życzkowski K. }\end{array}$ & $\begin{array}{l}\text { Czy można } \\
\text { porównywać jabłka } \\
\text { i gruszki? O danych } \\
\text { bibliometrycznych } \\
\text { w różnych } \\
\text { dziedzinach nauki }\end{array}$ & Nauka & 2013 & 23 & $\begin{array}{l}\text { Bibliometria } \\
26 / 42\end{array}$ \\
\hline 21 & $\begin{array}{l}\text { Nicholas D., } \\
\text { Rodríguez- } \\
\text {-Bravo B., } \\
\text { Boukacem- } \\
\text {-Zeghmo- } \\
\text { uri Ch., } \\
\text { Rodríguez- } \\
\text {-Bravo B., Xu } \\
\text { J., Watkinson } \\
\text { A., Abrizah } \\
\text { A., Herman E., } \\
\text { Świgoń M. } \\
\end{array}$ & $\begin{array}{l}\text { Peer review: } \\
\text { The experience } \\
\text { and views of early } \\
\text { career researchers }\end{array}$ & $\begin{array}{l}\text { Learned } \\
\text { Publishing }\end{array}$ & 2017 & 23 & Autor ang. \\
\hline 22 & Kisilowska M. & $\begin{array}{l}\text { Biblioteka w sieci- } \\
\text {-sieć w bibliotece: } \\
\text { wybrane społeczne } \\
\text { i kulturowe aspekty } \\
\text { współczesnego } \\
\text { bibliotekarstwa }\end{array}$ & & 2010 & 21 & Autor \\
\hline 23 & Kulczycki E. & $\begin{array}{l}\text { Wykorzystanie } \\
\text { mediów } \\
\text { społecznościowych } \\
\text { przez akademickie } \\
\text { uczelnie wyższe } \\
\text { w Polsce. Badania } \\
\text { w formule otwarte- } \\
\text { go notatnika }\end{array}$ & $\begin{array}{l}\text { Komuniko- } \\
\text { logia. Teoria } \\
\text { i praktyka } \\
\text { komunikacji }\end{array}$ & 2012 & 21 & $\begin{array}{l}\text { Komunikacja } \\
\text { naukowa 18/40 }\end{array}$ \\
\hline
\end{tabular}




\begin{tabular}{|c|c|c|c|c|c|c|}
\hline 1 & 2 & 3 & 4 & 5 & 6 & 7 \\
\hline 24 & Cisek S. & $\begin{array}{l}\text { Metoda analizy } \\
\text { i krytyki } \\
\text { piśmiennictwa } \\
\text { w nauce } \\
\text { o informacji } \\
\text { i bibliotekoznaw- } \\
\text { stwie w XXI wieku }\end{array}$ & $\begin{array}{l}\text { Przeglad } \\
\text { Biblioteczny }\end{array}$ & 2010 & 20 & $\begin{array}{l}\text { Nauka o informa- } \\
\text { cji } 1 / 51 \\
\text { Informatologia } \\
9 / 34 \\
\text { Zarządzanie in- } \\
\text { formacją } 93 / 100 \\
\text { Biblioteki akade- } \\
\text { mickie } 60 / 71 \\
\text { Komunikacja } \\
\text { naukowa } 23 / 40 \\
\text { Bibliometria } 40 / 42 \\
\text { Zachowania infor- } \\
\text { macyjne } 19 / 29\end{array}$ \\
\hline 25 & Kowalska M. & $\begin{array}{l}\text { Crowdsourcing } \\
\text { internetowy-pozy- } \\
\text { tywny wymiar par- } \\
\text { tycypacji spotecznej. } \\
\text { Konteksty-istota- } \\
\text {-uwarunkowania }\end{array}$ & & 2015 & 19 & $\begin{array}{l}\text { Informatologia } \\
15 / 34 \\
\text { Komunikacja } \\
\text { naukowa } 24 / 40 \\
\text { Teoria informacji } \\
83 / 100 \\
\text { Architektura in- } \\
\text { formacji } 22 / 28\end{array}$ \\
\hline 26 & $\begin{array}{l}\text { Nicholas D., } \\
\text { Rodríguez- } \\
\text {-Bravo B., } \\
\text { Boukacem- } \\
\text {-Zeghmo- } \\
\text { uri Ch., } \\
\text { Rodríguez- } \\
\text {-Bravo B., Xu } \\
\text { J., Watkinson } \\
\text { A., Abrizah } \\
\text { A., Herman E., } \\
\text { Swigoń M. } \\
\end{array}$ & $\begin{array}{l}\text { So, are early career } \\
\text { researchers } \\
\text { the harbingers } \\
\text { of change? }\end{array}$ & $\begin{array}{l}\text { Learned } \\
\text { Publishing }\end{array}$ & 2019 & 18 & Autor ang. \\
\hline 27 & Roman W.K. & $\begin{array}{l}\text { Podstawy zarzadza- } \\
\text { nia informacja }\end{array}$ & & 2012 & 18 & $\begin{array}{l}\text { Zarządzanie } \\
\text { informacją 2/100 }\end{array}$ \\
\hline 28 & Gmerek K. & $\begin{array}{l}\text { Archiwa interneto- } \\
\text { we po obu stronach } \\
\text { Atlantyku-Internet } \\
\text { Archive, Wayback } \\
\text { Machine oraz UK } \\
\text { Web Archive }\end{array}$ & Biuletyn EBIB & 2012 & 16 & $\begin{array}{l}\text { Biblioteki } \\
\text { akademickie } \\
43 / 71\end{array}$ \\
\hline 29 & $\begin{array}{l}\text { Kamińska- } \\
\text {-Czubała B. }\end{array}$ & $\begin{array}{l}\text { Zachowania infor- } \\
\text { macyjne w życiu } \\
\text { codziennym: } \\
\text { informacyjny świat } \\
\text { pokolenia } Y\end{array}$ & & 2013 & 16 & $\begin{array}{l}\text { Zachowania } \\
\text { informacyjne } \\
1 / 29\end{array}$ \\
\hline
\end{tabular}




\begin{tabular}{|c|c|c|c|c|c|c|}
\hline 1 & 2 & 3 & 4 & 5 & 6 & 7 \\
\hline 30 & Malak P. & $\begin{array}{l}\text { Indeksowanie } \\
\text { treści: porównanie } \\
\text { skuteczności metod } \\
\text { tradycyjnych } \\
\text { i automatycznych }\end{array}$ & & 2012 & 15 & Autor \\
\hline 31 & Świgoń M. & $\begin{array}{l}\text { Information limits: } \\
\text { Definition, typology } \\
\text { and types }\end{array}$ & $\begin{array}{l}\text { Aslib Proce- } \\
\text { edings }\end{array}$ & 2011 & 15 & $\begin{array}{l}\text { Bariery informa- } \\
\text { cyjne } 27 / 29\end{array}$ \\
\hline 32 & $\begin{array}{l}\text { Wojciechow- } \\
\text { ska M. }\end{array}$ & $\begin{array}{l}\text { Studium zarza- } \\
\text { dzania niemate- } \\
\text { rialnymi zasobami } \\
\text { organizacyjnymi } \\
\text { bibliotek }\end{array}$ & & 2014 & 15 & $\begin{array}{l}\text { Biblioteki akade- } \\
\text { mickie } 63 / 71 \\
\text { Zasoby informa- } \\
\text { cyjne } 39 / 100\end{array}$ \\
\hline 33 & $\begin{array}{l}\text { Górny M., } \\
\text { Lewandow- } \\
\text { ski R. }\end{array}$ & $\begin{array}{l}\text { The state of deve- } \\
\text { lopment of digital } \\
\text { libraries in Poland }\end{array}$ & Program & 2010 & 14 & Autor ang. \\
\hline 34 & Kolasa W.M. & $\begin{array}{l}\text { Specific character } \\
\text { of citations } \\
\text { in historiography } \\
\text { (using the example } \\
\text { of Polish history) }\end{array}$ & $\begin{array}{l}\text { Scientome- } \\
\text { trics }\end{array}$ & 2012 & 14 & Autor ang. \\
\hline 35 & Kulczycki E. & $\begin{array}{l}\text { Zasady oceny } \\
\text { czasopism } \\
\text { humanistycznych } \\
\text { i ich rola w parame- } \\
\text { tryzacji jednostek } \\
\text { naukowych }\end{array}$ & Nauka & 2014 & 14 & $\begin{array}{l}\text { Czasopisma } \\
\text { naukowe 22/100 }\end{array}$ \\
\hline 36 & $\begin{array}{l}\text { Kulczycki E., } \\
\text { Rozkosz E.A., } \\
\text { Drabek A. }\end{array}$ & $\begin{array}{l}\text { Ocena ekspercka } \\
\text { jako trzeci wymiar } \\
\text { ewaluacji krajo- } \\
\text { wych czasopism } \\
\text { naukowych }\end{array}$ & Nauka & 2016 & 14 & $\begin{array}{l}\text { Bibliografia za- } \\
\text { łącznikowa 14/19 }\end{array}$ \\
\hline 37 & Babik W. & $\begin{array}{l}\text { O natłoku } \\
\text { informacji } \\
\text { i związanym } \\
\text { z nim przeciążeniu } \\
\text { informacyjnym }\end{array}$ & $\begin{array}{l}\text { Człowiek-me- } \\
\text { dia-edukacja }\end{array}$ & 2010 & 13 & $\begin{array}{l}\text { Zarządzanie in- } \\
\text { formacją } 33 / 100 \\
\text { Teoria informacji } \\
8 / 100 \\
\text { Ekologia } \\
\text { informacji 6/21 } \\
\text { Kultura informa- } \\
\text { cyjna } 2 / 39\end{array}$ \\
\hline 38 & Boruszewski J. & $\begin{array}{l}\text { Jakość } \\
\text { i wiarygodność } \\
\text { informacji } \\
\text { w infobrokerstwie }\end{array}$ & $\begin{array}{l}\text { Lingua ac } \\
\text { Communitas }\end{array}$ & 2012 & 13 & $\begin{array}{l}\text { Infobrokerstwo } \\
2 / 11\end{array}$ \\
\hline
\end{tabular}




\begin{tabular}{|c|c|c|c|c|c|c|}
\hline 1 & 2 & 3 & 4 & 5 & 6 & 7 \\
\hline 39 & $\begin{array}{l}\text { Derfert-Wolf } \\
\text { L. }\end{array}$ & $\begin{array}{l}\text { Archiwizacja } \\
\text { Internetu - wpro- } \\
\text { wadzenie i przegląd } \\
\text { wybranych inicjatyw }\end{array}$ & Biuletyn EBIB & 2012 & 13 & $\begin{array}{l}\text { Biblioteki akade- } \\
\text { mickie 49/71 }\end{array}$ \\
\hline 40 & Głowacka E. & $\begin{array}{l}\text { Badania wartości } \\
\text { ekonomicznej usług } \\
\text { biblioteczno-in- } \\
\text { formacyjnych i ich } \\
\text { wpływu } \\
\text { na otoczenie }\end{array}$ & Biblioteka & 2011 & 13 & $\begin{array}{l}\text { Biblioteki akade- } \\
\text { mickie } 45 / 71 \\
\text { Zasoby informa- } \\
\text { cyjne } 42 / 100\end{array}$ \\
\hline 41 & Kisilowska M. & $\begin{array}{l}\text { Przestrzeń } \\
\text { informacyjna } \\
\text { jako termin } \\
\text { informatologiczny }\end{array}$ & $\begin{array}{l}\text { Zagadnienia } \\
\text { Informacji } \\
\text { Naukowej }\end{array}$ & 2011 & 13 & $\begin{array}{l}\text { Kompetencje in- } \\
\text { formacyjne } 22 / 57 \\
\text { Teoria informacji } \\
67 / 100 \\
\text { Ekologia informa- } \\
\text { cji } 13 / 21 \\
\text { Środowisko infor- } \\
\text { macyjne } 1 / 21 \\
\text { Zachowania in- } \\
\text { formacyjne } 19 / 29 \\
\text { Działalność infor- } \\
\text { macyjna } 7 / 82 \\
\text { Przestrzeń infor- } \\
\text { macyjna } 1 / 44\end{array}$ \\
\hline 42 & Kotuła S.D. & $\begin{array}{l}\text { Komunikacja } \\
\text { bibliologiczna } \\
\text { wobec World } \\
\text { Wide Web }\end{array}$ & & 2013 & 13 & $\begin{array}{l}\text { Nauka o informa- } \\
\text { cji } 29 / 51 \\
\text { Informatologia } \\
29 / 34 \\
\text { Komunikacja } \\
\text { naukowa } 4 / 40 \\
\text { Wyszukiwanie } \\
\text { informacji 99/100 } \\
\text { Teoria informacji } \\
80 / 100 \\
\text { Obiekty informa- } \\
\text { cyjne } 4 / 5\end{array}$ \\
\hline 43 & $\begin{array}{l}\text { Nicholas D., } \\
\text { Rodríguez- } \\
\text {-Bravo B., } \\
\text { Boukacem-Ze- } \\
\text { ghmouri Ch., } \\
\text { Rodríguez- } \\
\text {-Bravo B., Xu } \\
\text { J., Watkinson } \\
\text { A., Abrizah } \\
\text { A., Herman E., } \\
\text { Świgoń M. } \\
\end{array}$ & $\begin{array}{l}\text { Sci-Hub: The new } \\
\text { and ultimate } \\
\text { disruptor? } \\
\text { View from the front }\end{array}$ & $\begin{array}{l}\text { Learned } \\
\text { Publishing }\end{array}$ & 2019 & 13 & Autor ang. \\
\hline
\end{tabular}




\begin{tabular}{|c|c|c|c|c|c|c|}
\hline 1 & 2 & 3 & 4 & 5 & 6 & 7 \\
\hline 44 & $\begin{array}{l}\text { Nicholas D., } \\
\text { Rodríguez- } \\
\text {-Bravo B., } \\
\text { Boukacem- } \\
\text {-Zeghmo- } \\
\text { uri Ch., } \\
\text { Rodríguez- } \\
\text {-Bravo B., Xu } \\
\text { J., Watkinson } \\
\text { A., Abrizah } \\
\text { A., Herman E., } \\
\text { Świgoń M. } \\
\end{array}$ & $\begin{array}{l}\text { Early career } \\
\text { researchers' quest } \\
\text { for reputation } \\
\text { in the digital age }\end{array}$ & $\begin{array}{l}\text { Journal } \\
\text { of Scholarly } \\
\text { Publishing }\end{array}$ & 2018 & 13 & Autor ang. \\
\hline 45 & Wendland M. & $\begin{array}{l}\text { Działanie } \\
\text { komunikacyjne } \\
\text { a przekazywanie } \\
\text { informacji }\end{array}$ & $\begin{array}{l}\text { Komuniko- } \\
\text { logia. Teoria } \\
\text { i praktyka } \\
\text { komunikacji }\end{array}$ & 2012 & 13 & $\begin{array}{l}\text { Teoria informacji } \\
2 / 100\end{array}$ \\
\hline 46 & Cisek S. & $\begin{array}{l}\text { "Metodologia } \\
\text { mieszana" } \\
\text { w badaniach nauki } \\
\text { o informacji } \\
\text { i bibliotekoznaw- } \\
\text { stwa }\end{array}$ & $\begin{array}{l}\text { Biblioteki, } \\
\text { informacja, } \\
\text { ksiażka: } \\
\text { interdyscypli- } \\
\text { narne bada- } \\
\text { nia i praktyka } \\
\text { w XXI wieku }\end{array}$ & 2010 & 12 & $\begin{array}{l}\text { Nauka } \\
\text { o informacji } 1 / 51 \\
\text { Informatologia } \\
16 / 34 \\
\text { Użytkownicy } \\
\text { informacji } 1 / 25 \\
\text { Zachowania in- } \\
\text { formacyjne } 17 / 29\end{array}$ \\
\hline 47 & Dahlberg I. & $\begin{array}{l}\text { Wissensorganisa- } \\
\text { tion: Entwicklung, } \\
\text { Aufgabe, Anwen- } \\
\text { dung, Zukunft }\end{array}$ & $\begin{array}{l}\text { Zagadnienia } \\
\text { Informacji } \\
\text { Naukowej }\end{array}$ & 2015 & 12 & $\begin{array}{l}\text { Organizacja } \\
\text { informacji 1/17 } \\
\text { Bibliografia za- } \\
\text { łącznikowa 3/19 }\end{array}$ \\
\hline 48 & Kolasa W.M. & $\begin{array}{l}\text { Kierunki badań } \\
\text { nad historią prasy } \\
\text { polskiej 1918-1939, } \\
\text { Cz. 1. Tendencje roz- } \\
\text { wojowe, typologia }\end{array}$ & $\begin{array}{l}\text { Rocznik } \\
\text { Historii Prasy } \\
\text { Polskiej }\end{array}$ & 2011 & 12 & $\begin{array}{l}\text { Bibliometria } \\
12 / 42\end{array}$ \\
\hline 49 & Osińska V. & $\begin{array}{l}\text { Wizualizacja } \\
\text { informacji: studium } \\
\text { informatologiczne }\end{array}$ & & 2016 & 12 & $\begin{array}{l}\text { Wizualizacja } \\
\text { informacji 1/23 }\end{array}$ \\
\hline 50 & Skórka S. & $\begin{array}{l}\text { Architekt } \\
\text { informacji - } \\
\text { kreator przestrzeni } \\
\text { informacyjnych }\end{array}$ & $\begin{array}{l}\text { Przeglad } \\
\text { Biblioteczny }\end{array}$ & 2011 & 12 & $\begin{array}{l}\text { Architektura } \\
\text { informacji } 1 / 28 \\
\text { Zasoby informa- } \\
\text { cyjne } 4 / 100 \\
\text { Srodowisko infor- } \\
\text { macyjne } 4 / 21 \\
\text { Przestrzeń infor- } \\
\text { macyjna } 1 / 44\end{array}$ \\
\hline 51 & Górny M. & $\begin{array}{l}\text { Key users of Polish } \\
\text { digital libraries }\end{array}$ & $\begin{array}{l}\text { The Electronic } \\
\text { Library }\end{array}$ & 2012 & 11 & Autor ang. \\
\hline
\end{tabular}




\begin{tabular}{|c|c|c|c|c|c|c|}
\hline 1 & 2 & 3 & 4 & 5 & 6 & 7 \\
\hline 52 & Hetmański M. & Świat informacji & & 2015 & 11 & $\begin{array}{l}\text { Teoria informacji } \\
1 / 100 \\
\text { Procesy informa- } \\
\text { cyjne } 46 / 53\end{array}$ \\
\hline 53 & $\begin{array}{l}\text { Kulczycki E., } \\
\text { Drabek A., } \\
\text { Rozkosz E.A. }\end{array}$ & $\begin{array}{l}\text { Publikacje } \\
\text { a zgłoszenia ewalu- } \\
\text { acyjne, czyli znie- } \\
\text { kształcony obraz } \\
\text { nauki w Polsce }\end{array}$ & Nauka & 2015 & 11 & $\begin{array}{l}\text { Czasopisma } \\
\text { naukowe 28/100 }\end{array}$ \\
\hline 54 & Osińska V. & $\begin{array}{l}\text { Wizualizacja } \\
\text { i wyszukiwanie } \\
\text { dokumentów }\end{array}$ & & 2010 & 11 & $\begin{array}{l}\text { Wizualizacja } \\
\text { informacji } 2 / 23\end{array}$ \\
\hline 55 & Świgoń M. & $\begin{array}{l}\text { Personal } \\
\text { Knowledge } \\
\text { Management } \\
\text { (PKM) and Personal } \\
\text { Employability } \\
\text { Management } \\
\text { (PEM)-Concepts } \\
\text { Based } \\
\text { on Competences }\end{array}$ & $\begin{array}{l}\text { Proceedings } \\
\text { of the 3rd } \\
\text { European } \\
\text { conference } \\
\text { on Intellec- } \\
\text { tual Capital. } \\
\text { University } \\
\text { of Nicosia, } \\
\text { Cyprus, } \\
18-19 \text { April } \\
2011\end{array}$ & 2011 & 11 & Autor ang. \\
\hline 56 & Drabek A. & $\begin{array}{l}\text { Bibliometryczna } \\
\text { analiza czasopism } \\
\text { naukowych } \\
\text { w dziedzinie nauk } \\
\text { spotecznych }\end{array}$ & & 2010 & 10 & Autor \\
\hline 57 & Głowacka E. & $\begin{array}{l}\text { Kultura oceny w bi- } \\
\text { bliotekach. Obszary, } \\
\text { modele i metody } \\
\text { badań jakości } \\
\text { zasobów oraz ustug } \\
\text { biblioteczno-infor- } \\
\text { macyjnych }\end{array}$ & & 2015 & 10 & Autor \\
\hline 58 & Kolasa W.M. & $\begin{array}{l}\text { Biblioteki cyfrowe } \\
\text { na świecie - } \\
\text { powstanie i rozwój }\end{array}$ & $\begin{array}{l}\text { Biblioteki } \\
\text { cyfrowe }\end{array}$ & 2012 & 10 & $\begin{array}{l}\text { Komunikacja } \\
\text { naukowa 35/40 } \\
\text { Biblioteki } \\
\text { cyfrowe 1/99 }\end{array}$ \\
\hline 59 & Kolasa W.M. & $\begin{array}{l}\text { Retrospektywny } \\
\text { indeks cytowań } \\
\text { w humanistyce }\end{array}$ & $\begin{array}{l}\text { Przeglad } \\
\text { Biblioteczny }\end{array}$ & 2011 & 10 & $\begin{array}{l}\text { Teoria informacji } \\
85 / 100 \\
\text { Bibliometria } \\
38 / 42\end{array}$ \\
\hline
\end{tabular}




\section{Bibliografia}

Beel, J., Gipp, B., Eilde, E. (2010). Academic Search Engine Optimization. Journal of Scholarly Publishing, 41(2), 176-190, https://doi.org/ 10.3138/jsp.41.2.176

Delgado López-Cózar, E., Orduna-Malea, E., Martín-Martín, A. (2019). Google Scholar as a Data Source for Research Assessment. In: W. Glänzel, H.F. Moed, U. Schmoch, M. Thelwall, (eds.), Springer Handbook of Science and Technology Indicators, (95-127). Springer International Publishing.

Halevi, G., Moed, H., Bar-Ilan, J. (2017). Suitability of Google Scholar as a Source of Scientific Information and as a Source of Data for Scientific Evaluation. Review of the Literature. Journal of Informetrics, 11(3), 823-834, https://doi.org/10.1016/j.joi.2017.06.005

Martin-Martin, A., Orduna-Malea, E., Harzing, A-W., Delgado López-Cózar, E. (2017). Can We Use Google Scholar to Identify Highly-cited Documents? Journal of Informetrics, 11(1), 152-163, https://doi.org/10.1016/j.joi.2016.11.008

Martin-Martin, A., Orduna-Malea, E., Delgado López-Cózar, E. (2018). A Novel Method for Depicting Academic Disciplines Through Google Scholar Citations: The Case of Bibliometrics. Scientometrics, 14, 1251-1273, https://doi.org/10.1007/s11192-017-2587-4

Babik, W., red. (2016). Nauka o informacji, Warszawa: Wydaw. SBP.

Osiński, Z. (2019). Analysis of the Thematic Overlap Between Library and Information Science and Other Sub-disciplines of the Social Communication and Media Sciences in Poland. Zagadnienia Informacji Naukowej - Studia Informacyjne, 57(2A), 28-44, https://doi.org/10.36702/zin.468

Osiński, Z. (2019). The Usefulness of Data from Web of Science and Scopus Databases for Analyzing the State of a Scientific Discipline. The Case of Library and Information Science. Zagadnienia Informacji Naukowej - Studia Informacyjne, 57(2A), 45-93, https://doi.org/10.36702/zin.469

Racki, G., Drabek, A. (2013). Cytowania i wskaźnik Hirscha: gdzie szukać, jak obliczać? [online]. Forum Akademickie, (2) [28.04.2021], https://prenumeruj.forumakademickie.pl/fa/2013/02/cytowaniai-wskaznik-hirscha-gdzie-szukac-jak-obliczac/

Siłka, P., Śleszyński, P., Jaworska, B. (2016). Cytowania członków komitetów naukowych Polskiej Akademii Nauk według Google Scholar, Zagadnienia Naukoznawstwa, 4(210), 529-560, htpps:// doi.org/10.24425/118025

Sosińska-Kalata, B. (2013). Obszary badań współczesnej informatologii (nauki o informacji), Zagadnienia Informacji Naukowej - Studia Informacyjne, 51(2), 9-41, https://doi.org/10.36702/zin.600

Stirbu, S., Thirion, P., Schmitz, S., Haesbroeck, G., Greco, N. (2015). The Utility of Google Scholar When Searching Geographical Literature: Comparison with Three Commercial Bibliographic Databases. The Journal of Academic Librarianship, 41(3), 322-329, https://doi.org/10.1016/j. acalib.2015.02.013

Śleszyński, P. (2013). Cytowania i oddziaływanie polskich ośrodków geograficznych według Google Scholar. Przeglad Geograficzny, 85(4), 599-627, https://doi.org/10.7163/PrzG.2013.4.5

Wróblewski, A.K. (2013). Pozycja nauki polskiej w międzynarodowych rankingach [online]. Studia BAS, 3(35), 89-106 [28.04.2021], http://orka.sejm.gov.pl/WydBAS.nsf/0/5FA50C2A6481F62FC1257BC200435A20/\$file/Infos_152.pdf 


\title{
Using Google Scholar to Identify the Most Cited Researchers and Their Research Papers. The Case of Polish Publications in the Field of Information Science
}

\begin{abstract}
Purpose/Thesis: The study seeks to determine whether Google Scholar allows the user to identify the most frequently cited researchers and their research papers published in Polish, and if the number of citations and the presence of keywords affect the publication's position in the ranking of the results yielded by GS. The author ranks Polish researchers and publications in the field of information science published in the period 2010-2019 to verify the hypothesis that the presence of a given publication in the search results and its position in the ranking is affected by the absence of keywords.

Approach/Methods: The author verifies and analyzes the data collected from Google Scholar. The sample comprises the results of forty queries, with key terms relating to information science, as well as names and surnames of researchers in the field.

Results and conclusions: The analysis of the sample disproves the hypothesis that Google Scholar search engine allows the user to identify the most frequently cited works and researchers. A significant part of scholarship indexed in GS does not appear in search results when the query is a phrase related to information science. Many frequently cited texts place very low in the ranking. The study also disproves the thesis that the number of citations determines a given publication's ranking. The vast majority of the bibliographic entries in the GS search results does not meet the user's needs. Use of appropriate key terms does not make it more likely that a given publication will be found.

Originality/Value: The work refutes the increasingly popular belief that Google Scholar can be professionally used to search for the most important (or rather, the most frequently cited) scientific papers and to rely on the number of citations as a basis for evaluating the papers published in Polish and the researchers publishing mainly in this language.
\end{abstract}

\section{Keywords}

Google Scholar. Information science. Research citation. Search results ranking.

Dr hab. ZBIGNIEW OSIŃSKI jest profesorem w Instytucie Nauk o Kulturze UMCS w Lublinie; specjalności: nauka o informacji, cyfrowa humanistyka. Najnowsze publikacje: Information Infrastructure of Contemporary Humanities and the Digital Humanities Development as a Cause of Creating New Information Barriers. A Polish case (Digital Scholarship in the Humanities, 2019), Analysis of the Thematic Overlap Between Library and Information Science and Other Sub-disciplines of the Social Communication and Media Sciences in Poland (Zagadnienia Informacji Naukowej - Studia Informacyjne, 2019), The Usefulness of Data from Web of Science and Scopus Databases for Analyzing the State of a Scientific Discipline. The Case of Library and Information Science (Zagadnienia Informacji Naukowej - Studia Informacyjne, 2019), Big data w praktyce badawczej humanistów - problemy metodyczne (Big Data w humanistyce i naukach społecznych, 2020).

\author{
Kontakt $z$ autorem: \\ zbigniew.osinski@gmail.com \\ Instytut Nauk o Kulturze \\ Wydziat Humanistyczny \\ Uniwersytet Marii Curie-Skłodowskiej \\ pl. Marii Curie-Sktodowskiej 4 \\ 20-031 Lublin
}

